
ND) Nordic Council
of Ministers

\title{
Assessing landscape experiences as a cultural ecosystem service in public infrastructure projects
}

From concept to practice

\section{in} phents (1) 



\section{Assessing landscape experiences as a cultural ecosystem service in public infrastructure projects}

From concept to practice

Marianne Zandersen, Henrik Lindhjem, Kristin Magnussen, Janne Helin and Rasmus Reinvang

TemaNord 2017:510 
Assessing landscape experiences as a cultural ecosystem service in public infrastructure projects

From concept to practice

Marianne Zandersen, Henrik Lindhjem, Kristin Magnussen, Janne Helin and Rasmus Reinvang

ISBN 978-92-893-4890-4 (PRINT)

ISBN 978-92-893-4891-1 (PDF)

ISBN 978-92-893-4892-8 (EPUB)

http://dx.doi.org/10.6027/TN2017-510

TemaNord 2017:510

ISSN 0.908-6692

Standard: PDF/UA-1

ISO 14289-1

(c) Nordic Council of Ministers 2017

Layout: NMR

Cover photo: unsplash.com

Print: Rosendahls

Printed in Denmark

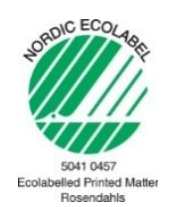

Although the Nordic Council of Ministers funded this publication, the contents do not necessarily reflect its views, policies or recommendations.

\section{Nordic co-operation}

Nordic co-operation is one of the world's most extensive forms of regional collaboration, involving Denmark, Finland, Iceland, Norway, Sweden, the Faroe Islands, Greenland, and Åland.

Nordic co-operation has firm traditions in politics, the economy, and culture. It plays an important role in European and international collaboration, and aims at creating a strong Nordic community in a strong Europe.

Nordic co-operation seeks to safeguard Nordic and regional interests and principles in the global community. Shared Nordic values help the region solidify its position as one of the world's most innovative and competitive. 


\section{Contents}

Preface

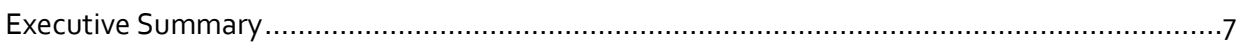

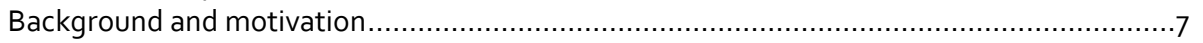

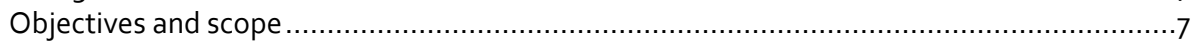

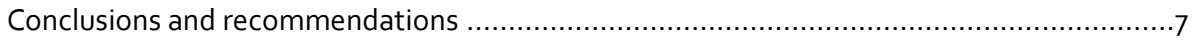

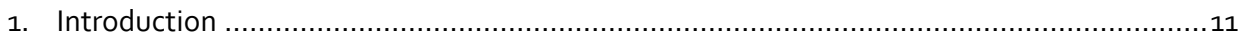

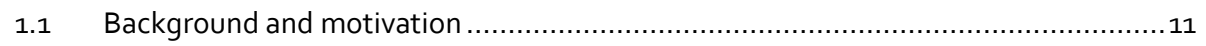

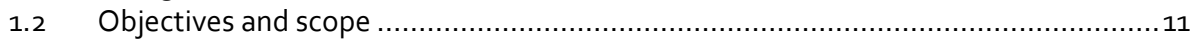

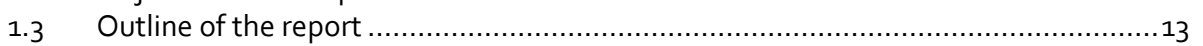

2. Assessing, valuing and incorporating landscape experiences in practice .........................15

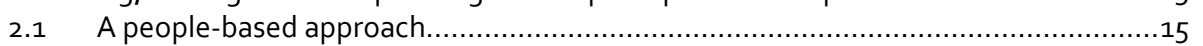

2.2 Making the landscape concept operational .................................................. 15

2.3 Valuation methods for landscape experiences ................................................ 21

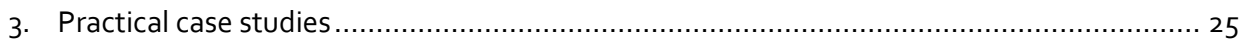

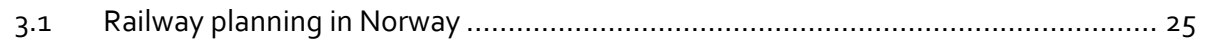

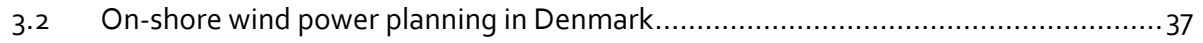

3.3 Off-shore wind power planning in Finland ...................................................... 49

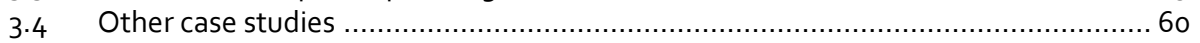

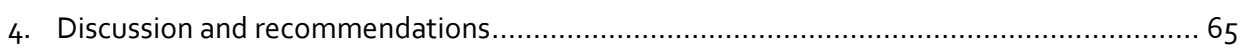

4.1 Lessons from applying our suggested stepwise method ................................... 65

4.2 Further work and integration of landscape experiences ....................................67

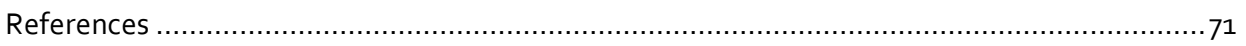

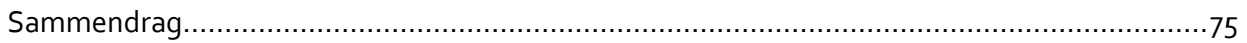

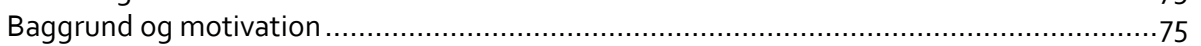

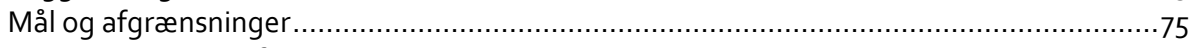

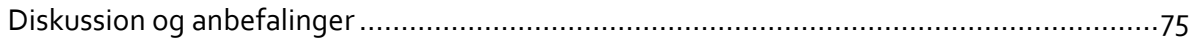





\section{Preface}

This report has been written by Marianne Zandersen and Janne Helin (both Danish Centre for Environment and Energy (DCE)/Department of Environmental Science, Aarhus University (AU), Henrik Lindhjem (Vista Analysis ${ }^{1}$ and Norwegian Institute for Nature Research), Kristin Magnussen (Vista Analysis ${ }^{1}$ ), Rasmus Reinvang (Vista Analysis). Ståle Navrud (Vista Analysis ${ }^{1}$ and Norwegian University of Life Sciences) has reviewed the report.

We would like to thank the following for their contributions, particularly in providing us with case study examples and references to literature: Göran Bostedt, Mattias Boman, Bengt Kriström, Runar Brännlund (all Swedish University of Agricultural Sciences), Cecilia Håkansson (KTH Royal Institute of Technology, Sweden), Jan Kofod Winther (Nature and Environment Repeal Committee, Denmark), Marketta Nummijärvi (Kauhajoki Municipality, Finland).

Any errors or omissions remain the responsibility of the authors. This project was funded by the Terrestrial Ecosystem Group (TEG) of the Nordic Council of Ministers. Britta Skagerfalt and (in the last part of the project) Petter Mahrs have been our main contacts and have managed the process excellently.

February 2017

Henrik Lindhjem

Project manager, Vista Analysis AS 



\title{
Executive Summary
}

\author{
Background and motivation
}

Phase 1 of this project documented that environmental impact assessments (EIA), costbenefit analyses (CBA) and spatial planning at sector, project and more strategic (higher) levels are often carried out without quantification of landscape impacts or assessment of the value of such impacts for human welfare (NCM 2015). Several indicators and methods have been developed to quantify and value landscape change and resulting ecosystem service (ES) loss in monetary or non-monetary terms, based on people's preferences stated in surveys or revealed in market behaviour. NCM (2015) surveyed these studies and various statistics in the Nordic context and found that undesirable landscape changes, especially from large public infrastructure projects, may give rise to potentially significant welfare losses related to degraded landscape experiences. These losses are currently largely unaccounted for in all Nordic countries' planning processes (NCM 2015).

Moving from the review and discussion of concepts, of what existing literature says about landscape values and selected decision contexts in the Nordic countries, to demonstrating how values of landscape experiences may be better incorporated in practical applications is the important challenge we address in this report.

\section{Objectives and scope}

The aim of this second phase of the project is to explore how the ecosystem service (ES) approach and values of landscape experiences can be better incorporated in practice in actual cases with potentially large landscape impacts.

\section{Conclusions and recommendations}

\section{Assessment of landscape experiences: a people-based approach}

We take as our point of departure the definition of landscape in the European Landscape Convention: "Landscape means an area, as perceived by people, whose character is the result of the action and interaction of natural and/or human factors." Article 5 of this convention emphasises an obligation to ensure the participation of the public in the definition and implementation of landscape policies, and requires the parties to the Convention to establish the necessary procedures for this to happen. 
Hence, people's preferences for landscape experiences should count (more) in policy processes involving significant landscape impacts.

\section{Cultural ecosystem services related to landscape experiences}

In order to make the landscape experience concept operational for assessment and planning, we simplify the categories of cultural ecosystem services related to landscape experiences (Table 1). The simplification involves replacing a set of more detailed service categories by two broad categories of "natural heritage" and "cultural heritage and identity". In addition, we have "recreational" and "aesthetic" services.

Table 1: Simplified overview of cultural ecosystem services (ESs) related to landscape experiences

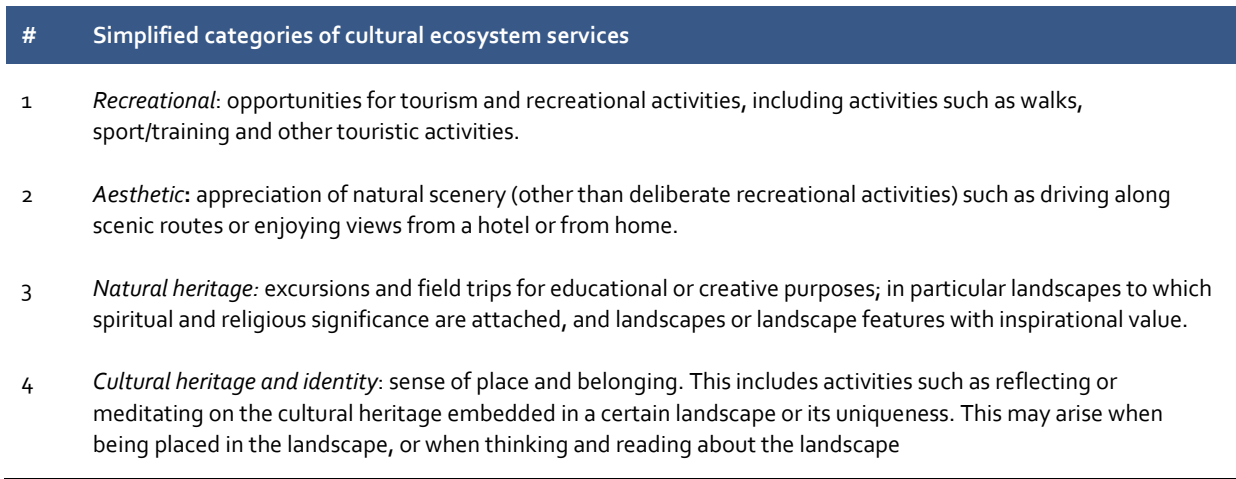

\section{A step-wise method to assess, value and incorporate impacts}

We develop a simple step-wise approach that use the ecosystem service categories in Table 1 to assess, value and incorporate impacts on landscape experiences in practice. The method can be applied in EIAs and in CBAs to help incorporate and quantify people's preferences and views. The impacts that projects such as transportation and energy infrastructures may have on landscape experiences depend very much on the location, scale and visual impacts. Impacts in the "everyday landscapes" in and around large population centres may be more important in welfare terms than impacts on more remote "iconic", low population density landscapes.

As landscape changes, ESs that people derive from the landscape will be more or less affected. As not all landscape changes affect ESs to a degree that warrants a closer appraisal, we suggest a step-wise method starting with a screening phase to determine the most important ESs that are affected. This is followed by a second step involving a more detailed appraisal and, where possible, monetary valuation of welfare changes for the most important ESs. Those impacts which cannot be valued in monetary terms are assessed qualitatively, but still with a view to how important these impacts are for people's welfare. 


\section{Overview of case studies of public infrastructure projects}

We have chosen three in-depth cases covering Norway (railway), Denmark and Finland (both wind power) which have illustrated the applicability of the step-by-step method outlined above; and a number of other cases from Denmark and Norway (both roads) and Iceland (energy projects) to illustrate the usefulness and challenges of incorporating impacts on landscape experiences.

The railway case in Norway is a fairly unique example where we had the opportunity to work on an actual, current case while the planning and analysis were unfolding. Specifically, a strategic environmental impact assessment (EIA) (i.e. the more general level before the project EIA level) was conducted with inputs in terms of data needs for a more thorough assessment of the welfare effects. This EIA did not include quantified information on affected populations and the size of impacts. But by making additional analysis and assumptions, and transfer values from the literature, we managed at least to illustrate potential welfare impacts for all main ES affected by the landscape changes. Even if the final decision on which railway route to construct is not yet made, we can still say that this case study has raised awareness of the importance of also valuing welfare losses of ES impacts in monetary terms.

The wind power case in Denmark was an EIA on the installation of four large onshore windmills at the outskirts of Copenhagen. The case was largely contested by the neighbouring municipality and residents due to expected visual disamenities. Although the project was granted a dispensation from the Nature Protection Act by the Ministry of Environment, the EIA was dismissed following a ruling by the Nature and Environment Appeal Committee. Applying the ES framework in the step-by-step method and valuing degradation of aesthetic services indicate a substantial negative value, which could have been central in the EIA conclusions compared to a purely qualitative description, which omitted one of the main impacts.

The wind power case in Finland was an EIA on a proposed off shore wind power park in proximity of the coastal Siipyy Village. The park was to be located in a designated area approved in the regional plan. However, local resistance caused a rejection of the project in the local plan and the project was stopped. Integrating monetary valuation of the impacts of the wind park on cultural ecosystem services related to landscape amenities in the EIA stage could have provided additional and vital information to local decision makers regarding not only the size of impact but also the preferences of affected population groups.

\section{Discussion and recommendations}

Although none of the strategic or project level ElAs from the in-depth cases applied the ES framework, they do include information on the state and type of change to the landscape that can be attributed to the different ESs. A number of lessons and recommendations can be drawn out from the in-depth case studies: 
- Much of the information readily available/collected in EIAs can be used at least to some extent to describe the state (i.e. how much of the different ecosystem services is present before the proposed change) and change indicators (i.e. which functions in the landscape may be changed after the proposed project is implemented).

- Applying an ES framework with assessment of impacts and significance on individual landscape related ESs, ensures that all relevant population groups are identified and none omitted.

- Impact quantification including size of population affected and spatial layout of impacts are key data to generate in landscape assessment processes before valuation is possible.

- Including additional geographic information systems (GIS) analyses, household and user surveys of different population groups in EIAs could to a large extent ensure that value transfers can be used to value changes in landscape related ESs.

- Existing surveys conducted as part of traditional EIAs could be extended to accommodate an ES framework.

- A two-step approach with first a screening, a scoring and then an in-depth analysis of selected ESs showed its usefulness, but would necessitate that additional information be generated in EIAs. This information would not necessarily come at a high cost, as it could be gathered as part of the existing procedures, and could greatly improve the quality of the EIAs.

- Information from ES-extended EIAs could also be useful as inputs into costbenefit analysis, which some projects will be subject to.

Our simple stepwise method is a first attempt to move the concept of landscape experiences to practical assessment. It has provided a first way to think about how landscape experiences can better be assessed in the analysis of public infrastructure projects with potentially large landscape impacts. The case studies have shown that even if information is sometimes lacking, the method makes an improvement over the current practice by helping in making public decisions stand on a firmer, more peoplebased footing. This means that the decision basis can be made more robust and focus on the key issue, i.e. how the affected people see the landscape impacts through their own eyes, so to speak.

Issues remain to be solved in terms of further refining and testing the step-wise method; having sufficient primary landscape valuation studies to draw on; distinguishing between landscape ESs that lend themselves readily to monetary valuation (recreation, aesthetic services) and those that should remain at a qualitative assessment level (cultural and natural heritage and sense of place); and integrating the method into guidelines for EIA and CBA. 


\section{Introduction}

\subsection{Background and motivation}

Phase 1 of this project documented that impact assessments, cost-benefit analyses and spatial planning at sector, project and more strategic (higher) levels are often carried out without quantification of landscape impacts or assessment of the value of such impacts for human welfare (NCM 2015). The report also made the link to loss of landscape experiences as a cultural ecosystem service (ES). Several indicators and methods have been developed to quantify and value landscape change and resulting ES loss in monetary or non-monetary terms, based on people's preferences stated in surveys or revealed in market behaviour. NCM (2015) surveyed these studies and various statistics in the Nordic context and found that undesirable landscape changes, especially from large public infrastructure projects, may give rise to potentially significant welfare losses related to degraded landscape experiences. These losses are currently largely unaccounted for in all Nordic countries planning processes (NCM 2015).

Moving from the review and discussion of concepts, of what existing literature says about landscape values and selected decision contexts in the Nordic countries, to demonstrating how values of landscape experiences may be better incorporated in practical applications remains an important challenge.

\subsection{Objectives and scope}

The aim of this second phase of the project is to explore how the ecosystem service (ES) approach and values of landscape experiences can be better incorporated in practice in actual cases with potentially large landscape impacts.

Phase 2 of this project specifically:

1. develops, based on the findings in phase 1 , a practical method or approach to assess, value and incorporate landscape experience as a cultural ES in practice

2. tailors and tests the method or approach to selected planning processes and tools in the Nordic countries, with emphasis on incorporating welfare implications of landscape change in cost-benefit analysis (CBA) considerations in various contexts.

We have chosen three in-depth cases covering Denmark, Finland and Norway, and some other cases from these and other Nordics to illustrate the usefulness and 
challenges of incorporating landscape impacts. ${ }^{2}$ The following cases, all covering large public infrastructure projects in different sectors and countries, have been chosen:

\subsubsection{In-depth cases}

- Railway planning in Norway.

- On-shore wind power planning in Denmark.

- Off-shore wind power planning in Finland.

\subsubsection{Other cases}

- Road planning in Norway.

- Road planning in Denmark.

- Energy projects in Iceland.

The in-depth cases follow the step-by-step method or approach outlined in the first part of the report, while the other cases illustrate different aspects of including landscape values in assessments and planning processes.

The wind power cases are based on planning processes that have been carried out. We investigate these cases with the following questions in mind:

- Establish baseline: To what extent does current practice integrate ES values of landscape? How have direct and indirect impacts on landscape experiences been handled (if at all)? Have important aspects been ignored?

- Improved practice: How could the ES perspective and values of landscape experiences have been included in this case?

- Effects: What is the extent of the values that were originally ignored? Other lessons from the case?

The railway case is a fairly unique example where we have had the opportunity to work on an actual, current case while the planning and analysis have been unfolding (NGARS 2016). ${ }^{3}$ Specifically, an environmental impact assessment (above the project level) has been carried out and we have provided our inputs into the process, in terms of data needs for a more thorough assessment of the welfare effects. We have tried to use available methods and data to value some of the ES impacts, including on landscape experiences, according to the approach we suggest in this report.

The other cases are based on studies of public infrastructure projects where monetary valuation has been carried out for impacts that also include landscape amenities.

\footnotetext{
${ }^{2}$ We have searched for suitable cases from Sweden through our research network and publications such as Kriström and Bergman (2014) and Söderholm (2014) without finding any suitable examples that could be included as short cases.

3 A so-called "konseptvalgutredning" (KVU) of a railway section, where the exact location of the line has not been decided.
} 


\subsection{Outline of the report}

The outline of the report is as follows. In chapter 2.1 we discuss the overall approach in terms of establishing a method or approach to assess, value and incorporate landscape experience as a cultural ES in practice. Chapter 2.2 briefly describes the non-market valuation methods suitable to value landscape experiences. We then test this approach in the mentioned cases in chapter 3. Finally, in chapter 4, we discuss the main lessons learned from the use of the method, possible improvements, and make recommendations for further work on integrating of landscape experiences in assessments and planning. 



\section{Assessing, valuing and incorporating landscape experiences in practice}

\subsection{A people-based approach}

Our working hypothesis is that assessments of landscape impacts of projects and policies would benefit from including an ecosystem service (ES) approach, as this allows for inclusion of cultural ES and (monetary and non-monetary) values that are often not fully captured in current landscape assessment practises, nor reflected in subsequent decisions or priorities. The ES approach is based more on the preferences of the people affected by such landscape impacts, and their experienced welfare loss, rather than on the opinions of experts. This people-based approach is also well aligned with the intention behind the European Landscape Convention (see below).

This current phase of the project attempts, based on findings in phase 1, to develop a method or approach to better incorporate landscape experiences as ESs into assessments of impacts in practice, especially in environmental impact assessment (EIA) and cost benefit analysis (CBA) contexts. In this chapter, we first briefly recapitulate some of the key concepts and the categories of ESs that are the most closely associated with landscape changes from NCM (2015). We then outline a simple step-wise approach to using an ES approach to assess and value landscape impacts. In the next chapter, we test and illustrate this approach on three in-depth case studies, and a number of other case studies from the Nordic countries.

\subsection{Making the landscape concept operational}

\subsubsection{Landscape defined}

We take as our point of departure the definition of landscape in the European Landscape Convention: "Landscape means an area, as perceived by people, whose character is the result of the action and interaction of natural and/or human factors." The Convention's article 5, emphasises an obligation to ensure the participation of the public in the definition and implementation of landscape policies, and requires the parties to the Convention to establish necessary procedures to achieve this. Hence, people's preferences for landscape experiences need to count (more) in policy processes with significant landscape impacts. 
Landscape is a multisensory experience of physical surroundings that forms a whole and which can be constituted by natural (wild), rural, peri-urban or urban elements in various degrees. Landscapes exist not only as physical entities that are the source of direct sensory experience, but also as cultural constructs with symbolic meanings for certain people. NCM (2015) discusses various meanings and professional landscape research traditions, and how to operationalize the concept.

\subsubsection{Landscape experience as cultural ecosystem service}

From a practical perspective, we consider "landscape experience" as a form of cultural ecosystem service $(E S)^{4}$ derived from landscapes (or where landscape is important), The main classes of cultural ESs associated with landscape experiences have been described in NCM (2015) (see Table 2).

Table 2: Overview of cultural ecosystem services related to landscape experiences

\# Cultural ecosystem services related to landscape experiences

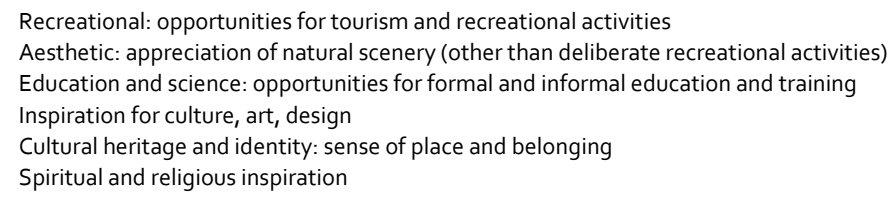

Source: Based on de Groot et al. (2010).

These six types of cultural ES have a large degree of overlap in many cases with landscape experiences (see NCM 2015, Table 3.1 and discussion). We try to separate the recreational services from the aesthetic ones by defining activities that are primarily/deliberately recreational, i.e. the purpose is not primarily to view and experience aesthetic aspects of landscapes, as "Recreational" services. . Activities where aesthetic experience is the primary objective are classified as "aesthetic" services.

In this report, we look more closely at how landscape as a cultural ES can be operationalized in sector planning and assessments. For this purpose, we simplify the list of cultural ESs related to landscape further. This is done in order to make the list manageable and to avoid duplications arising from the fact that several services overlap, and can be mapped simultaneously and with the same method.

\footnotetext{
4 Man benefits in a multitude of ways from ecosystems. Collectively, these benefits are known as ES. The ES concept was popularized by the Millennium Ecosystem Assessment (2005), which grouped ecosystem services into four broad categories (1) Provisioning, such as the production of food and water; (2) Regulating, such as the control of climate and disease;

(3) Cultural, such as spiritual and recreational benefits; (4) Supporting, normally seen as services that are necessary for the production of all other services. This classification still stands, though the European Commission and others have refined the classification in various directions (not important for our discussion here).
} 
Table 3 shows a simplified list of cultural ESs related to landscape, which are relevant for planning processes and assessments of e.g. planning of roads, wind parks, electric transmission lines and biogas facilities.

\section{Table 3: A simplified list of cultural ecosystem services (ESs) related to landscape experiences}

\# Simplified categories of cultural ecosystem services

1 Recreational: opportunities for tourism and recreational activities, including activities such as walks, sport/training and other touristic activities.

2 Aesthetic: appreciation of natural scenery (other than deliberate recreational activities) such as driving along scenic routes or enjoying views from a hotel or from home.

$3 \quad$ Natural heritage: excursions and field trips for educational or creative purposes, in particular landscapes to which spiritual and religious significance are attached and landscapes or landscape features with inspirational value.

$4 \quad$ Cultural heritage and identity: sense of place and belonging. This includes activities such as reflecting or meditating on the cultural heritage embedded in a certain landscape or the uniqueness of a certain landscape. This may take place when being placed in the landscape, or when thinking and reading about the landscape

Source: de Groot et al. (2010)

The simplification in Table 3 involves constructing two broad categories of "natural heritage" and "cultural heritage and identity" and replace the service categories 3, 4, 5 and 6 in Table 2. Although we through this simplification have strived to avoid overlap between the four categories, we cannot exclude the possibility that there could be cases of such overlap.

\subsubsection{A step-wise method to using the ES approach to assess and value landscape impacts}

Landscape is not a static element but is constantly undergoing change, reflecting activities by human society to varying degrees. The impacts that projects such as transportation and energy infrastructures may have on landscape experiences depend very much on the location, scale and visual impacts. For instance, changes to landscapes closer to population centres will affect more people, even if the landscape is not as aesthetically attractive as in a more remote location. Hence, impacts in the "everyday landscapes" in and around large population centres may be more important in welfare terms, than impacts on more "iconic" landscapes where fewer people live and experience them daily (see e.g. figure 3.1, the "landscape experience pyramid" in NCM 2015). Values or the welfare impact of landscape changes are therefore to a large extent driven by accessibility and proximity to people.

As landscape changes, ESs that people derive from the landscape will be affected. As not all landscape changes affect ecosystem services to a degree that warrants a closer appraisal, we suggest a step-wise method starting with a screening phase to determine the most important ESs that are affected, followed by a more detailed appraisal and, where possible, monetary valuation of welfare changes for those ecosystem services that have been found most important. Those who cannot be valued in monetary terms will be assessed qualitatively, with the view to still consider such impacts in terms of importance 
for people's welfare. The step-wise method we suggest is inspired by the review in NCM (2015), and more specifically based on Atkins and Metroeconomica (2013) and Vista Analyse (2016a). The method consists of two general steps:

- Level 1-Screening.

- Level 2-Detailed assessment.

Note that this method has been used to assess the full range of ES impacts of e.g. transport projects. In our case, we limit the use of the method to impacts on landscape experiences.

We have in our approach not considered specifically how other landscape assessment methods, such as the landscape character method, common in some countries (see NCM 2015) could be utilized. We have, however, followed procedures and data availability in environmental impact assessments (EIA) more generally, though our emphasis here is on assessing the welfare impacts (which are also the most suitable for CBA-type considerations).

Level 1 - Screening

The first step consists of a screening process. The screening serves to determine the level of impacts that a given infrastructure or construction project may have on the different cultural ESs associated with landscape experiences. As a first step, the level of cultural ESs prior to the change in landscape should be determined. Then, an assessment of the change of functions in the landscape with respect to the different cultural ESs provided to people is needed. Finally, we need to determine how many people will be impacted by the change in service provision.

Table 4 provides examples of the type of information that would be needed in order to determine which ecosystem services are most important to assess in more detail. The approach is predominantly based on evaluations by people potentially affected and their behaviour. 
Table 4: Identifying state, change and impacts

\begin{tabular}{|c|c|c|c|}
\hline $\begin{array}{l}\text { Cultural } \\
\text { ecosystem service }\end{array}$ & (State indicator) & $\begin{array}{l}\text { Which functions* in the } \\
\text { landscape will be changed? } \\
\text { (Change indicator) }\end{array}$ & $\begin{array}{l}\text { How many people will be } \\
\text { impacted, and who are they? } \\
\text { (Impact indicator) }\end{array}$ \\
\hline Recreational & $\begin{array}{l}\text { Number/area of landscape } \\
\text { and wildlife features with } \\
\text { stated recreational value. }\end{array}$ & $\begin{array}{l}\text { Landscape features. } \\
\text { Attractive wildlife. }\end{array}$ & $\begin{array}{l}\text { Actual use (frequency, duration, } \\
\text { visitor numbers, type of use). }\end{array}$ \\
\hline Aesthetic & $\begin{array}{l}\text { Number/area of landscape } \\
\text { features with stated } \\
\text { appreciation. }\end{array}$ & $\begin{array}{l}\text { Aesthetic quality of the } \\
\text { landscape, based on e.g. } \\
\text { structural diversity, } \\
\text { "greenness", tranquillity. }\end{array}$ & $\begin{array}{l}\text { Expressed aesthetic value, e.g.: } \\
\text { Number of houses bordering } \\
\text { natural areas, number of users of } \\
\text { scenic routes etc. }\end{array}$ \\
\hline \multirow[t]{3}{*}{ Natural heritage } & $\begin{array}{l}\text { Presence of landscape } \\
\text { features with special } \\
\text { educational and scientific } \\
\text { value/interest. }\end{array}$ & $\begin{array}{l}\text { Landscape features with } \\
\text { special educational and } \\
\text { scientific value/interest. }\end{array}$ & $\begin{array}{l}\text { Number of school classes visiting. } \\
\text { Number of scientific studies etc. }\end{array}$ \\
\hline & $\begin{array}{l}\text { Number/area of landscape } \\
\text { features or species with } \\
\text { inspirational value. }\end{array}$ & $\begin{array}{l}\text { Landscape features or species } \\
\text { with inspirational value to } \\
\text { human arts etc. }\end{array}$ & $\begin{array}{l}\text { Number of books, paintings, etc. } \\
\text { using ecosystems as inspiration. }\end{array}$ \\
\hline & $\begin{array}{l}\text { Presence of landscape } \\
\text { features or species with } \\
\text { spiritual value. }\end{array}$ & $\begin{array}{l}\text { Landscape features or species } \\
\text { with spiritual and religious } \\
\text { value. }\end{array}$ & $\begin{array}{l}\text { Number of people who attach } \\
\text { spiritual or religious significance to } \\
\text { ecosystems. }\end{array}$ \\
\hline $\begin{array}{l}\text { Cultural heritage } \\
\text { and identity }\end{array}$ & $\begin{array}{l}\text { Number/area of culturally } \\
\text { important landscape features } \\
\text { or species. }\end{array}$ & $\begin{array}{l}\text { Culturally important } \\
\text { landscape features or species. }\end{array}$ & $\begin{array}{l}\text { Number of people "using" e.g. } \\
\text { forests for cultural heritage and } \\
\text { identity. }\end{array}$ \\
\hline
\end{tabular}

Note: *Ecological process and/or component providing the service or influencing its availability.

Source: Based on de Groot et al. (2010).

Following the process of identifying the state, change and impacts of landscape experiences, the next steps are to:

- Score the changes likely to occur.

- Score the impacts for the relevant population.

- Assess the importance of a change in services to people, i.e. the welfare consequence based on the combination of the two abovementioned scores.

Scoring changes and impacts is based on a rating from no impacts or not relevant $($ score $=0$ ) to high $($ score $=3$ ) for each of the cultural ecosystem services (see Table 5). 
Table 5: Scoring changes and impacts

\begin{tabular}{|c|c|c|c|}
\hline Cultural ES & Rating & $\begin{array}{l}\text { Degree of change } \\
\text { (impact on landscape) }\end{array}$ & $\begin{array}{l}\text { Importance/value to people } \\
\text { (impact on people) }\end{array}$ \\
\hline Recreational & $\begin{array}{l}\text { o-none } \\
1 \text {-low } \\
2 \text {-middle } \\
3 \text {-high }\end{array}$ & & \\
\hline Aesthetic & $\begin{array}{l}\text { o-none } \\
1 \text {-low } \\
2 \text { - middle } \\
3 \text {-high }\end{array}$ & & \\
\hline Natural heritage & $\begin{array}{l}\text { o-none } \\
1 \text {-low } \\
2 \text {-middle } \\
3 \text {-high }\end{array}$ & & \\
\hline Cultural heritage and identity & $\begin{array}{l}\text { o-none } \\
1 \text {-low } \\
2 \text {-middle } \\
3 \text {-high }\end{array}$ & & \\
\hline
\end{tabular}

Assessing the importance is made by applying the values noted in Table 6 .

Table 6: Welfare consequence by cultural ecosystem service

\begin{tabular}{|c|c|c|c|c|c|}
\hline \multirow{2}{*}{$\begin{array}{l}\text { \# Cultural } \\
\text { ecosystem service }\end{array}$} & & \multicolumn{4}{|c|}{ Importance (value) to people } \\
\hline & & $\begin{array}{l}0-\text { not relevant } \\
\text { in the area }\end{array}$ & 1 -low & 2 -middle & 3-high \\
\hline \multirow[t]{4}{*}{ Degree of impact } & o-none & o & o & o & o \\
\hline & $1-$ low & o & o & 0 & $-1+$ \\
\hline & 2 - middle & o & o & $-1+$ & $--/++$ \\
\hline & 3-high & o & $-1+$ & $--/++$ & $--/++$ \\
\hline
\end{tabular}

ESs that score $o$ in Table 6 are omitted from level 2 assessment, as they have been found to have no or low importance. Depending on the context, one can argue to further assess all ecosystem services with at least one minus (-) or one plus (+); or only those with two or more minuses or pluses. We propose the former for level 2; i.e. including all services that score one or more pluses or minuses, because they may have a large importance when aggregated over the affected population 
Level 2 - detailed assessment of landscape impacts on key cultural ecosystem services

The detailed assessment serves to quantify in monetary or non-monetary terms the welfare changes due to changes in landscape experiences for the most important ecosystem services, identified in level 1.

Important factors to consider in level 2 are:

- How many households are affected, and what geographical area is affected?

- How many units are affected (e.g. number of recreational days)?

- How large is the welfare change per household or per unit (e.g. due to reduced quality of recreational days)?

- What is the availability and quality of substitute sites?

Recreation and aesthetic appreciation lend themselves more readily to monetary valuation of impacts (see discussion in NCM 2015), than natural and cultural heritage services, which are often more intangible and hence more difficult to assess in monetary terms.

The next section briefly describes the different monetary and non-monetary approaches to valuing landscape experiences, and techniques for transferring monetary values (termed benefit or value transfer).

\subsection{Valuation methods for landscape experiences}

Which methods do we have available for assessing monetary and non-monetary values of such cultural ecosystem services related to landscape experience? We provide a brief overview of these below, with reference to Table 7 and on our review in NCM (2015). We will utilise the methodological toolbox in the in-depth cases in chapter 3.

Table 7: Matrix of main landscape experiences and valuation methods (crosses indicating suitability of method)

\begin{tabular}{|c|c|c|c|c|c|c|c|}
\hline \multirow[t]{2}{*}{$\begin{array}{l}\text { Landscape } \\
\text { experience }\end{array}$} & \multicolumn{3}{|c|}{$\begin{array}{l}\text { Revealed preference } \\
\text { methods }\end{array}$} & \multicolumn{2}{|c|}{ Stated preferencemethods } & \multicolumn{2}{|c|}{ Study of human-landscape interaction } \\
\hline & $\begin{array}{l}\text { Travel } \\
\text { cost }\end{array}$ & $\begin{array}{l}\text { Hedonic } \\
\text { price }\end{array}$ & Avoid & $\begin{array}{l}\text { Contingent } \\
\text { valuation }\end{array}$ & $\begin{array}{l}\text { Choice } \\
\text { experiments }\end{array}$ & $\begin{array}{l}\text { Field studies } \\
\text { of use and } \\
\text { attitudes* }^{*}\end{array}$ & $\begin{array}{l}\text { Mapping of cultural } \\
\text { significance (text } \\
\text { study) }\end{array}$ \\
\hline Recreation & $x$ & & $x$ & $x$ & $x$ & $x$ & \\
\hline $\begin{array}{l}\text { Aesthetic } \\
\text { appreciation }\end{array}$ & & $\mathrm{x}$ & $x$ & $x$ & $x$ & $x$ & \\
\hline $\begin{array}{l}\text { Cultural heritage } \\
\& \text { sense of place }\end{array}$ & & & & $x$ & $x$ & $x$ & $x$ \\
\hline Natural heritage & & & & & & $x$ & $x$ \\
\hline
\end{tabular}

Note: *Qualitative description and assessment. Field studies of landscape related behaviour and attitudes. Mapping of cultural importance using cultural expressions.

**Spiritual, religious, inspiration \& symbolic, education science, art. 
The monetary valuation methods can be divided into revealed and stated preference methods. Revealed preference methods study how people behave in actual markets connected to the ecosystem service in question, and derive values from people's actual behaviour in these markets. The travel cost method derive the economic value of recreational activities, based on the visitor's incurred costs for transportation and time used to conduct their activity in a specific recreational site, and the number of visits they make to the site. The travel cost method is only suitable for valuing the current value of accessing recreation services at a site, and needs to be supplemented with contingent behavioural data or expert assessments of changes in recreational use in order to value changes in recreational services. The methods rely on the collection of user data.

Hedonic pricing methods derive the economic value people place on environmental characteristics such as views, distance to urban parks etc. by analysing data on all characteristics of residential and recreational homes as well as their market prices. This method can be applied to assess welfare changes when visual appreciation is affected.

There are also a range of other methods that measures such experiences utilizing market behaviour and prices of products and services that can directly or indirectly be linked with landscape experiences. These include damage costs avoided, substitute costs methods and replacement cost methods, and are based on estimating the values of ecosystem services using either the costs of avoiding damage due to a reduction in e.g. landscape amenity, the cost of replacing environmental assets (e.g. enhancing landscape qualities elsewhere), or the cost of providing substitute services (e.g. another recreation site). These methods, of which only avoidance cost is listed in Table 7 are applicable for valuing the changes in welfare when recreational services and aesthetics are affected.

The stated preference methods utilize surveys where people state their preferences for a hypothetical change in the quality and/or quantity of ESs, in terms of their willingness to pay (WTP) to achieve a specified improvement in landscape aesthetics or avoid a loss in landscape aesthetics. WTP can be derived directly by the Contingent valuation method - CVM), or indirectly in Choice Experiments (CE) by asking respondents repeatedly to choose among landscape programs described in terms of scenic quality attributes (e.g. degree of openness, trees or other vegetation cover, views etc.) and costs. By analysing their choices we can estimate what value they place on e.g. the different scenic quality attributes of a forest landscape; like more or less trees, deciduous or coniferous species, more or less clearings, light, lakes and constructed facilities such as benches, tracks etc. (see e.g. Czajkowski et al. 2014).

While the contingent valuation method typically values landscape (change) as a whole, choice experiments assume that people may be able to value the component parts of a landscape. The former is perhaps closer to how people normally view landscapes, i.e. as a holistic experience (Swanwick et al. 2007). The stated preference methods are the only ones that can capture non-use values, as value measurement is not based on tracing actual behaviour (i.e. use). Also, the stated preference methods are the only ones that can estimate the economic value of changes before they occur, without resorting to benefit transfer methods. The CVM method is illustrated in the Norwegian and Danish short cases on quantifying preferences for protecting different 
types of landscapes from road encroachment when building new motorways in Denmark (see chapter 3.4).

In addition to these monetary valuation methods, it is possible to use value transfer methods (Navrud and Ready 2007) (not mentioned explicitly in Table 7 as these are not primary valuation methods). This approach assumes that values for an ES determined by a valuation study in one geographical location, often termed "study site" (or from many locations, if more than one primary study is used as the basis for transfer) can be transferred and used in another location. This "other location" is typically termed the "policy site", where there is need for value information, but no time and/or resources to carry out a primary valuation study. The applicability of this approach depends on e.g. the decision context and the required precision needed for the value estimate (Lindhjem and Navrud 2008). The method has been used for landscape values in the past (Santos 2007), but it may be harder methodologically than for other environmental goods, due to the complexity of landscape values and especially because they tend to be very site specific (Ayala et al. 2014). We will return to the issue of value transfer and use in practice in chapter 3 , as this is the most common method in practice. Among the in-depth case studies, value transfer of CE estimates is applied in the Finnish case to assess the WTP to reduce the visual disamenities of a planned off-shore wind farm by locating it further away from the coast (see chapter 3.3). The Norwegian case study applies value transfer from hedonic price (HP) studies for landscape aesthetic effects, from travel cost and contingent valuation (CV) studies for recreation, CV studies for cultural heritage impacts, and CV studies for nature heritage (non-use values). The Danish case on wind farms (See chapter 3.2) applies value transfer of HP results to value visual disamenities of land-based windmills.

The non-monetary valuation methods, to the far right in Table 7, are a less clearly defined group of methods than the monetary valuation methods. The non-monetary methods have their origin in different disciplines and subjects including cultural geography, psychology, philosophy, sociology and anthropology, as well as professional areas, notably planning and landscape architecture (Swanwick 2009). Daniel et al. (2012) mention a few examples. A more thorough review of values and nonmonetary methods is provided by Kelemen et al. (2015). A set of non-monetary valuation methods we mention in the table is called "study of human-landscape interaction" are various field studies and mapping of cultural significance. These methods include qualitative description (non-monetary valuation) of the degree and nature of interaction between humans and a certain landscape based on field studies of behaviour and mapping of the historical and cultural importance (using cultural expressions, i.e. texts and other representations). Other non-monetary methods we consider in the case studies in chapter 3 are based on current approaches in EIA, for example the "plus and minus method" used in Norway (see chapter 3.1 for details). Our main emphasis is, however, on the monetary valuation methods. 



\section{Practical case studies}

\subsection{Railway planning in Norway}

\subsubsection{Introduction to case and area}

This chapter is based on an analysis at the (semi) strategic level (Konseptvalgutredning$\mathrm{KVU}$ ), which was carried out to assess a potential connection between two existing railway lines in the southern part of Norway, called "Sørlandsbanen" and "Vestfoldbanen", by building a new line - called Grenlandsbanen - from the district of Grenland in the south-eastern part of Telemark county, to the western part of Aust-Agder county. This area does not have a railway today. The project area includes the municipalities of Porsgrunn, Skien, Bamble, Kragerø and Gjerstad (see map in Figure 1).

The central city- and work centre - called "the city band" - in this project area is concentrated around Porsgrunn and Skien, which are the historical city centres in this region, called Grenland. Most of the project area consists of coastal landscapes and interior forest landscapes.

The so-called city-band is surrounded by listed cultural landscapes in northeast, and forest areas in east and west. Along the eastern side of the valley between Skien and Porsgrunn we find a marked ridge which divides the development areas. On the western side, where the development pressure is hardest, the developed area has spread all over the valley and partly up the hillsides. The most important agricultural areas in Grenland are situated on the eastern and northern side of the city-band. Housing and industrial development in areas with agricultural land imply potential conflicting interests. During recent years, the transformation of agricultural land to other land use has been extensive in Telemark County than in the neighbouring counties. 
Figure 1: Railway project area. Orange colour illustrates the primary area of influence of the project. Light orange illustrates wider area of influence

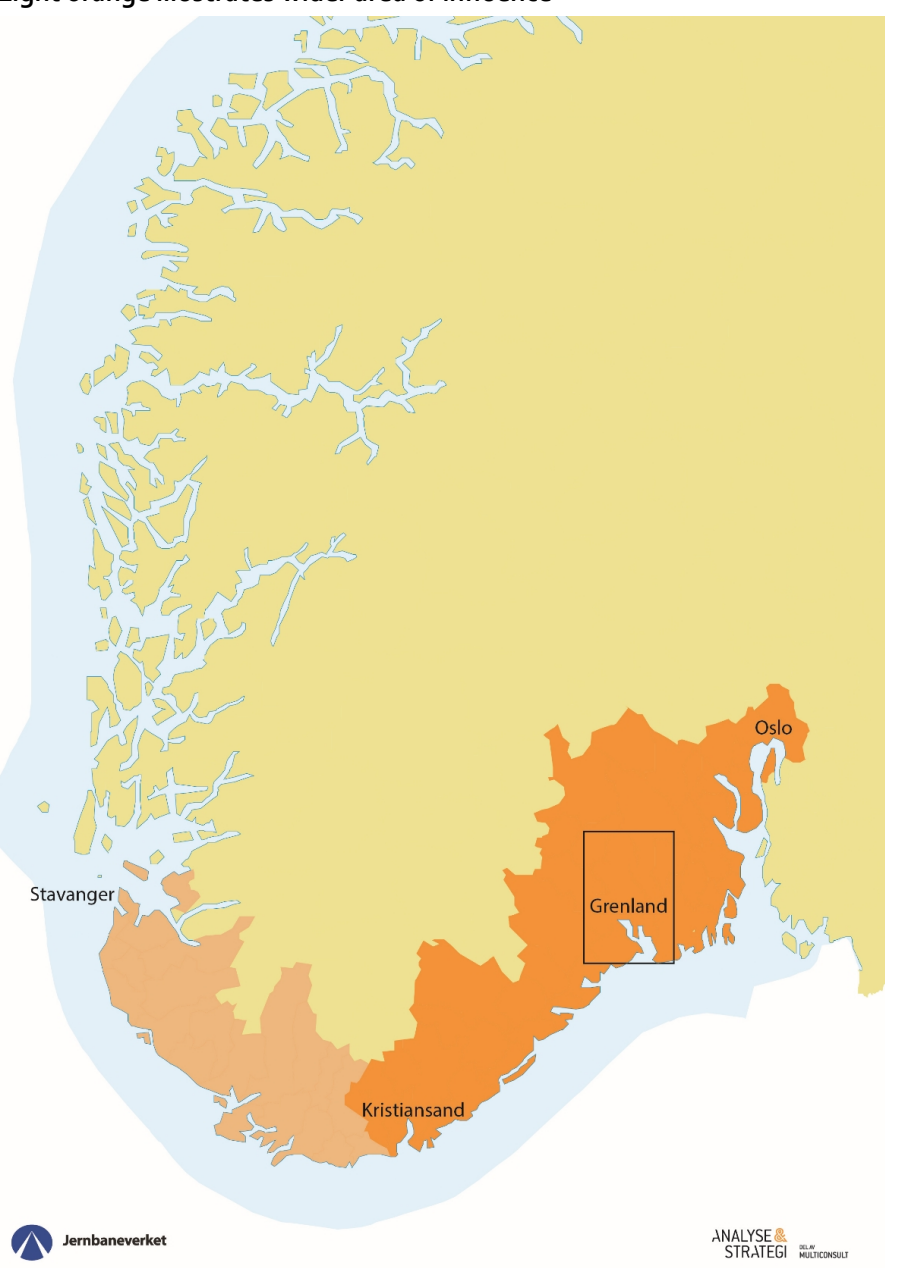

Source: NGARS (2016).

The cost-benefit analysis (CBA) and Environmental Impact Assessment (EIA) for the Grenlandsbanen railway project is carried out at a higher, more strategic level than standard CBA and EIA project appraisals (termed "Konseptvalgutredning" in Norwegian), In these analyses environmental impacts are usually described using a simplified version of the non-monetary "plus-and-minus methodology" (see section 3.1.2 for details.). However, the Norwegian Government's Agency for Railway Services (NGARS) initiated a case study which tests the use of the ecosystem services (ES) approach aiming at valuing some of the important ES impacts in monetary terms. The case study utilises the information collected for the "plus-and-minus method" together with simple unit value transfer methods.

This railway case is a fairly unique example where we have had the opportunity to work on an actual, current case while the planning and analysis have been unfolding (NGARS 2016). Specifically, in a strategic environmental impact assessment (EIA) 
(above the project level) we had the opportunity to provide inputs and request data to enable for a more thorough assessment of the welfare impacts. We have used available methods and data to value some of the ES impacts, including impacts on cultural ecosystem services related to landscape experiences, according to the approach we suggest in Chapter 2.

\subsubsection{Current practice and value assessment of landscape experience}

According to Norwegian law (regulations on Environmental Impact Assessment, pursuant to the Planning and Building Act), ElAs shall be carried out for projects of a certain size and character. The purpose of EIA is, according to $\S_{1}$ in the regulations: "..to ensure that impacts for the environment and society are considered when plans are prepared, and when it is decided if, and under which terms, the plans are to be carried out.

Further, there is a so-called "assessment rule", which states that all larger public projects shall be assessed sufficiently to ensure good decisions for society. For larger projects it is stated that a Cost-benefit analysis (CBA) should be carried out, following the rules for Cost-benefit analysis for public projects stated by the Ministry of Finance in 2014 and the guidelines for best practice CBA developed from the Norwegian Government Agency for Financial Management (NGAFM 2014).

For project assessment at the overarching strategic level, like the Grenlandsbanen project, the rules for how environmental and landscape effects should be assessed are less strict than at the lower level (spatial plans at local municipality level).

The NGARS is responsible for some large railway projects all over Norway. Their projects typically involve large costs and benefits to society, and potentially substantial environmental impacts. NGARS has developed their own guidelines for CBA, including evaluation of environmental impacts. For assessment of environmental impacts, however, they state that the assessment should follow the guidelines and detailed methodology developed by the Norwegian Public Road Administration (NPRA) who has worked particularly on combining the tools of CBA and EIA for their road projects, and has developed guidelines - the so-called Manual $V_{712}$ - for incorporating CBA as well as EIA regulations and guidelines (NPRA 2014).

Several other public agencies have adopted NPRA's guidelines as their own, particularly the methodology for non-priced effects and EIA. This has been done either by adapting NPRA's guidelines to other sectors, or by stating in that NPRA's guidelines can be used to assess environmental impacts in CBAs (and EIAs) in these other sectors.

In the following section we will provide a brief description of how landscape impacts are included in the present edition of the NGAFM and NPRA manuals.

\subsubsection{Description of current assessment guideline}

According to the guidelines from NGAFM, costs and benefits of projects and measures should first be quantified in physical units, and then valued in monetary units to the extent possible, either by use of market prices (if these exist) or by use of valuation methods developed for non-market goods and services (as briefly discussed in Chapter 2). 
Whether an effect should be valued in monetary terms or not depends on whether this is justifiable, professionally and considering the costs of conducting costly primary valuation studies compared to the benefits of receiving this "extra" information. The impacts that are not valued in monetary terms must be assessed and highlighted. These impacts should be quantified to the extent possible, and the impacts that cannot be quantified should be assessed qualitatively.

NGAFM's guidelines recommend what they call "the plus-and-minus method", which is equivalent to the method recommended by NPRA (2014). This recommends the so-called "impact fan" ("konsekvensviften"), or, alternatively, a qualitative, verbal assessment and statement for these non-priced impacts.

The plus-and-minus method is based on NPRA's manual V712 (NPRA 2014), and is effectively a non-monetary valuation or rating method. The manual identifies five categories of environmental impacts (that are currently not based on the ecosystem service approach): 5

- Landscape/aesthetics impacts.

- Recreation and local community impacts.

- Nature and biodiversity impacts.

- Cultural heritage, monuments and cultural environment impacts.

- Natural resources impacts.

Consequences (or impacts) for landscape/aesthetic effects are assessed on a scale ranging from very negative impact (- - - ) to very positive impact $(++++)$. The impact of a project or measure is a function of "value" (not considered monetarily), and the scope/size of the effect. The value of an area or resource is a measure of how valuable the affected place (area or resource) is, while the scope/size deals with the size of the change (impact) that the project or measure leads to for the area or resource in question.

The value of a landscape is graded as either small, medium, or large, and the size is graded from large negative, via medium negative, and little/no change to medium positive, and large positive. In the $V_{712}$ manual there are guidelines for how the geographical area for non-priced impacts should be delimited, and there are detailed descriptions of the grading of value and size for the landscape (and the other environmental impacts in the bullet list above), to be considered. The consequences (impacts) of a project or measure is compiled by use of the "impact fan", see Figure 2.

As noted in NCM (2015), this method originates from the EIA profession and is more an expert-driven process than one that emphasises people's preferences and their associated welfare changes.

5 In the current revision of the guideline (planned for 2017) these categories will be kept (largely) as they are, but ES may be incorporated to some extent in the descriptions under each impact category. 
Figure 2: "Impact fan" ("konsekvensvifte") also called the "plus-and-minus methodology" for nonpriced impacts. Left axis: Large positive to large negative scope of impact from top to bottom, Right axis: Small, medium, large value. The combination of the two dimensions yield an overall impact or consequence assessment

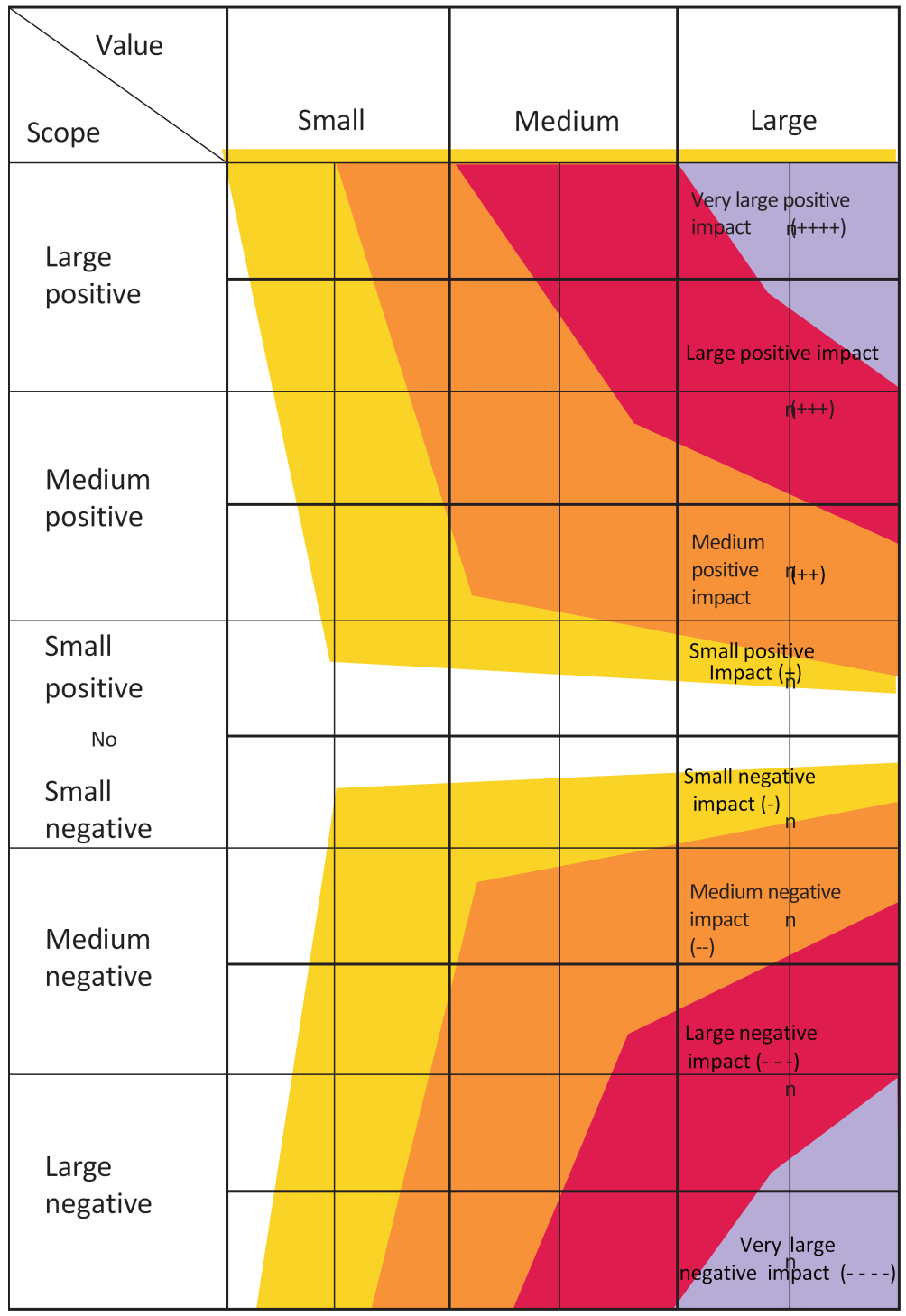

Source: NPRA (2014).

NGAFM (2014) states that this method (in principle) may be used for all non-priced impacts, not just environmental impacts.

\subsubsection{How landscape experience values were included}

For this project a non-priced assessment using the plus-and-minus-method described above, as well as a pilot project with the attempt to price important environmental impacts was carried out (Magnussen and Navrud 2016). The analysis included all 
environmental impacts, including impacts on landscape. Since this case project already had identified the relevant cultural ecosystem services related to landscape experiences and identified which ones were going to be valued in monetary terms, we skip the level 1 screening process here, and focus on level 2 - the detailed assessment of landscape impacts on key cultural ecosystem services related to landscape experiences, in Table 7 (see Chapter 2).

The selected cultural ecosystem services related to landscape experience were:

- Recreation.

- Aesthetic Services.

- Natural heritage.

- Cultural heritage.

Level 2 - detailed assessment

Level 2 includes a detailed assessment of landscape impacts on key cultural ecosystem services. The detailed assessment serves to quantify in monetary or non-monetary terms the welfare changes due to changes in landscape experiences for the most important ecosystem services, identified during level 1. This is shown briefly for case Grenlandsbanen in the following. A more thorough discussion of the impacts and the process for arriving at the relevant value assessments can be found in Magnussen and Navrud (2016).

According to a screening in the report (Magnussen and Navrud 2016), we assessed the four different routing alternatives for building the railway lines (the four "concepts" called I.1, M.1, M.2 and Y.1), see Figure 3. In addition to the cultural ecosystem services related to landscape experience, Magnussen and Navrud (2016) also considered the impacts on provisional ecosystem services in terms of agricultural production (which we do not discuss further here). 
Figure 3: Four different routing alternatives for building the railway line (the four "concepts", called from left to right in the map I.1, M.1, M.2 and Y.1)

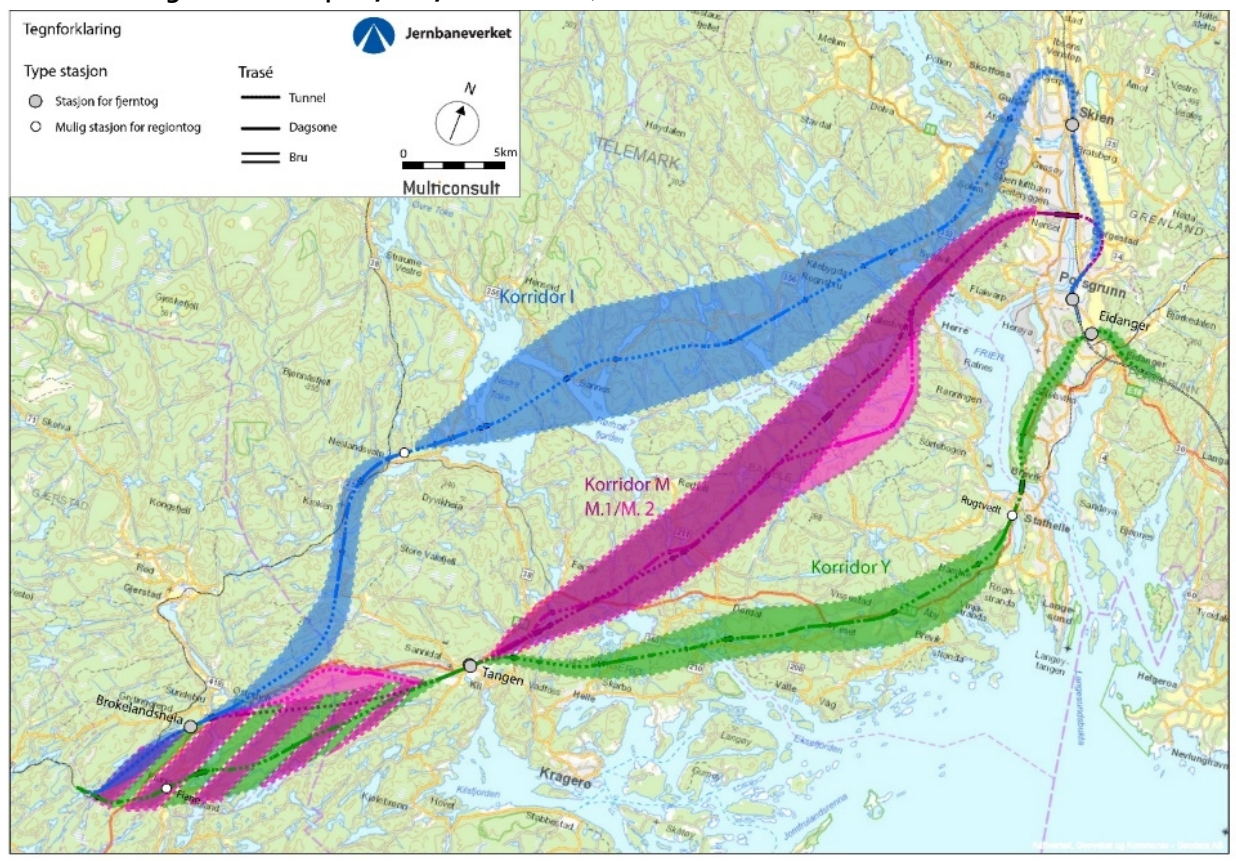

Source: NGARS (2016).

\subsubsection{Steps in value assessment for each ecosystem service impacted}

There was neither time nor money for primary valuation studies for any of the affected ecosystem services in this project. Hence, we had to use value (benefit) transfer for value assessment. We followed the steps described for good practice value transfer (see e.g. Navrud 2007), which includes identifying relevant and good studies to transfer from and identification of relevant affected populations.

Further we had to decide on the relevant unit for valuation (for example value per recreational day lost, non-use-value for lost natural heritage areas etc.) and unit value. Likewise, for each ecosystem service we had to try to identify the affected population. Both these steps involve uncertainties, which we will see in the following. In the next section we will describe very briefly how these steps looked like for one of the services; aesthetic services. More details can be found in Magnussen and Navrud (2016).

\subsubsection{Value assessment for impacts on aesthetic services}

The value unit used is percentage value reduction for leisure homes in different distances from the suggested railway lines. Using these values, we estimate the present value of reduced welfare for the affected households directly. These values represent the present value of reduced aesthetic values for the household owning leisure homes only. It does not include negative effects and reduced values for other users (than the 
owners and their household), even though these may also experience reduced recreation values.

\subsubsection{The number of affected leisure homes and house prices}

Table 8 shows the number of leisure homes in different distances from the suggested alternative routes. The table shows that there are no leisure homes within the 20 meter zone (defined as the "project zone" in urban areas) and only two within 200 meters (defined as the "influence zone" in urban areas). In the different routes, there are 1 to 4 houses within 50 meters outside urban areas, and 40 to 105 houses in the influence zone (1000-meter zone) outside urban areas.

The hedonic price studies in Norway (and abroad) that have assessed change in house prices due to railways and electric transmission lines find a drop in residential house prices of about $5 \%$ at a distance up to approximately 100-150 meters from the line. This means that these studies can only be used to assess impacts on properties in a small part of what is defined as the "influence zone" for railway projects (200 and 1,000 meters from the line in urban and rural areas, respectively). Thus, we assume that there is no impact on houses more than 150 meter from the line; and that leisure houses are affected in the same way as residential houses. Both these assumptions probably result in underestimation of the impacts, as there might be impacts outside the 150 meter zone, and leisure home prices are probably more sensitive to negative landscape aesthetic impacts than residential houses (as people escape to their leisure homes to enjoy peace and undisturbed landscape). The number of houses which is assumed to be within 150 meters from the line in the different alternative routes/concepts are shown in Table 8 . Field data collection was limited, and view shed analyses were not carried out in this strategic EIA. At this strategic level, the EIA is predominantly a desk-based study.

\subsubsection{Value estimates}

According to the procedure described above, the loss in value of leisure homes due to being close to a railway line, including aesthetic services from landscape changes, is very low; with a present value of approximately 0.5 to 1.0 million Norwegian kroner (NOK). This is due to the fact that there are only a few leisure homes located near the planned railway lines, and the estimated value loss for each of them is rather small. We have assumed the same average market price of NOK 1.5 million for all leisure homes along all suggested lines (as the average price for leisure homes in inland forested areas in this part of Norway). However, we are aware that leisure homes by the sea have a higher average price. It is therefore reasonable to assume that the monetary impact (in mill NOK) on leisure homes in concept Y.2 (the coastal route) could be somewhat higher than reported in Table 8 . Note that the reduction in property prices observed in hedonic prices studies, which we have transferred estimates from here, does not represent an annual welfare loss but the present value of welfare losses to their owners from this landscape aesthetic impact. 
These values are also reproduced in Table 9 under "aesthetic services".

Table 8: The number of leisure homes assumed to be affected, and the reduced prop-erty values (in present values) inform the four alternative railway concepts (I.1, M.1, M.2, and Y.2)

\begin{tabular}{|c|c|c|c|c|}
\hline & 1.1 & M.1 & M.2 & Y.2 \\
\hline The number of leisure homes which may experience reduced price & 6 & 7 & 8 & 16 \\
\hline Average prices for leisure homes* (mill. NOK) & 1.5 & 1.5 & 1.5 & 1.5 \\
\hline Present value of value reduction ( 5 per cent of house value) (mill. NOK) & $(6 \times 1.5 \times 0.05=) 0.5$ & 0.5 & 0.6 & 1.2 \\
\hline
\end{tabular}

Note: * *nformation from Norway's property price statistics for 2015

3.1.9 Value assessment for impacts on other cultural ecosystem services related to landscape experience

Table 9 summarises estimates of lost present value for each of the four cultural ecosystem services related to landscape experience: recreation, aesthetic services, natural heritage and cultural heritage. Table 9 also provides the total present value of the negative impacts on landscape related cultural ecosystem services over the project lifetime (40 years), using a social discount rate of four percent per year. This accrues to NOK 100-400 million, depending on the route alternative/concept.

These estimates do not included relative price adjustments, i.e. that the relative value of these ESs may increase more than the bundle of goods used to calculate the consumer price index (CPI). Thus, we have used the $\mathrm{CPI}$ for value transfer over time. Neither have we included an expected growth in population (and thereby an increased "affected" population who will have WTP to avoid these impacts on ecosystem services). Including these factors would tend to increase the estimated value of ES losses.

On the other hand, we have assumed that the ES losses would start to incur already this year (2016). If the losses arise later, as it will in reality, ${ }^{6}$ present values of costs will be lower due to discounting of future costs.

The total present value of reduced welfare from cultural ecosystem services related to landscape experience is estimated to be in the order of a few hundred million NOK. Although this is a large number, it is not very large compared to the overall costs of this railway project. We have not found similar valuation studies we can compare our estimates to. The non-priced assessment of environmental impacts of this railway project (COWI 2016), however, conclude that most environmental effects are small to moderate, and imply rather low level of conflicts. For landscape aesthetics the nonpriced assessment conclude that alternative I.1 and M.1 have a low negative impact on the landscape, while alternative $M .2$ and $Y .2$ have medium negative impacts. Alternative $\mathrm{I.1}$ and M.1 have the lowest priced effects on landscape as well. The difference to M.2 is small, while $Y .2$ has the largest environmental costs for the landscape.

${ }^{6}$ The planning horizon from a KVU until the building of the railway can be rather long. In the latest version of the costbenefit analysis for the project, it was assumed that the first year with regular trains on the railway, would be 2035 . 
For most of the alternative routing concepts the largest reduction in welfare is connected to loss of recreation close to home, together with the loss of use- and nonuse values for cultural heritage and reduced natural heritage services (non-use values), which are considerable in some concepts.

Reduced recreational values were estimated using an average unit value per recreational day of NOK 75 (based on value transfer from previous travel cost and contingent valuation studies in Norway), counting the number of people who live close to the alternative lines; and due to lack of empirical data, assuming that 25 to 50 per cent of their current recreation value in this area is lost due to the new railway routes

The reduced values for cultural and natural heritage are estimated in a similar way, transferring unit values in terms of WTP/household/year from previous Norwegian Contingent Valuation studies of non-use values of preserving biodiversity in forests and preserving cultural heritage objects, respectively. The unit values are then combined with an expert assessment of how many households will have their welfare reduced by impacts on these two cultural ESs.

From the table it seems like aesthetic services do have a minor impact. However, it was assumed that aesthetic values for the people who live in residential areas close to the railway lines are included in their recreational value, and aesthetic services for the travellers with the new railway lines are not included. Thus, the e aesthetic values include only impacts on leisure homes.

Overall, Concept Y.2 seems to have has the lowest cultural ES loss in monetary terms. This is mainly due to smaller reductions in values related to recreation and cultural heritage services. This again is because fewer people are assumed to be affected by this route/concept. 
Table 9: Estimated illustration of present value (cost) of impacts on ecosystem services for alternative concepts. Present value in million NOK for each land-scape related ecosystem service

\begin{tabular}{|c|c|c|c|c|c|}
\hline \multirow[t]{2}{*}{ Ecosystem Service } & \multicolumn{4}{|c|}{ Concept } & \multirow[t]{2}{*}{ Comment/explanation } \\
\hline & 1.1 & M.1 & M.2 & Y.2 & \\
\hline Recreation & $70-140$ & $70-140$ & $70-140$ & $11-22$ & Expected reduced value for recreation. \\
\hline Aesthetic services & 0.5 & 0.5 & 0.6 & 1.2 & $\begin{array}{l}\text { Addition to aesthetic services included in } \\
\text { recreation values (see row above). Potential } \\
\text { change in aesthetic services for the travellers } \\
\text { (traveling experiences) is not included. Potential } \\
\text { negative effects of living close to the railway lines } \\
\text { for houses because of noise in urban areas are } \\
\text { not included here, since they are included as a } \\
\text { priced effect in another part of the case project } \\
\text { (NOK/train km). }\end{array}$ \\
\hline Natural heritage & $16-64$ & $32-128$ & $32-128$ & $48-192$ & $\begin{array}{l}\text { Reduced natural heritage values are supposed to } \\
\text { be related to impact on INON areas*, selected } \\
\text { nature types and nature conservation areas. }\end{array}$ \\
\hline Cultural heritage & $25-150$ & $17-100$ & $17-100$ & $3-16$ & $\begin{array}{l}\text { Impacts and reduced values are relatively low due } \\
\text { to many tunnels in important areas for cultural } \\
\text { heritage. Some town areas of value for cultural } \\
\text { heritage in Skien and Porsgrunn will be impacted } \\
\text { by getting railway lines close to them. }\end{array}$ \\
\hline $\begin{array}{l}\text { Rough estimates for } \\
\text { total present value of } \\
\text { cost for impacts on } \\
\text { landscape experiences }\end{array}$ & $150-405$ & 137-395 & $139-400$ & $94-268$ & \\
\hline
\end{tabular}

Note: $\quad$ *INON areas = natural areas without significant technical installations and human impacts within a distance of $1-5 \mathrm{~km}$.

\subsubsection{Lessons learned}

One important lesson from this case study is that while transferred unit valued for the culture ESs could be constructed, we often lacked information about the size of the impact, and the size of the population affected to aggregate these impacts over. The latter is particularly important as it will greatly affect the aggregated value of the ES impacts.

Based on the data available from the EIA at this strategic level, there is only little information available about who can be assumed to be affected by the landscape impacts, e.g. i) how many who will actually experience reduced possibilities or quality of recreation and landscape aesthetics, ii) which alternatives (substitutes) they may have for these recreational areas and landscape experiences; and iii) how many actually do have values for natural and cultural heritage. Due to lack of information about this, and because it was not possible to investigate in more detail how many would be affected, we have applied simplified rules of thumb in some of the calculations and included for example everyone in the building zone, the influence area, or communities or counties through which the railway lines are crossing. 
Table 9 illustrates that concept Y.2 have the lowest economic costs for cultural ecosystem services related to landscape experience. This alternative was, however, ranked as the worst of the four according to the non-monetary evaluation carried out by COWI (2016). This difference between the monetary and non-monetary assessments illustrates the importance of valuing impacts of traditionally non-priced impacts, building on people's preferences and their WTP to assess the welfare loss in a CBA context.

There is considerable uncertainty both in using the expert assessments as the basis for valuing ecosystem services (particularly because the strategic EIA lacks the detail/depth of a project level EIA), and in the unit prices used for value transfer. This uncertainty can be reduced with more detailed expert judgments of impacts and more advanced value transfer methods at the next, more detailed level of EIA. However, the largest reduction in uncertainty would be achieved by conducting new user surveys, and primary valuation studies of the affected ecosystem services. These new valuation studies should also be constructed with the aim of value transfer to be used in future cost-benefit analysis at other sites.

One must keep in mind that the methodology for non-monetary assessment has been developed to assess environmental impacts. Thus, this is example of monetization of ecosystem services must be considered a pilot study.

The advantage of the plus-and-minus method for non-monetary assessment of environmental effects is that it gives a systematic, unified and professional compilation of non-priced impacts, highlights non-priced impacts in the analysis and gives a rather pedagogic description of these impacts.

From an economic point of view an advantage of the plus-and-minus methodology is that it highlights that the positive and negative impacts should be assessed with respect to both size and significance ("value", though not considered in monetary terms). This is an approach which parallels the approach for assessment of priced impacts in economic analyses (i.e. unit price/value times the units affected provide the aggregate economic value).

On the other hand, there are some potential disadvantages, mainly related to misuse of the method, e.g. by lack of documentation of how value and size is assessed or lack of objective assessment of value and size. According to NGAFM (2014), a verbal description of non-priced impacts may be used as an alternative. However, they stress that even if a verbal description is used, a thorough assessment and description of the significance/value and size of the impact in question should be the basis for the assessment. Each environmental effect is evaluated according to the value/significance of the resource impacted and size of impact, in order to define the consequence (impact) - using the "impact fan".

The ES framework as such is rarely included in existing Norwegian guidelines and manuals for CBA or EIA (as noted in NCM 2015), but substantial work is currently ongoing in order to include and operationalise this approach, and to value more of the environmental effects in monetary terms. This research is important and necessary to be able to incorporate this approach in guidelines, handbooks, and as the standard practices in project assessments. 


\subsubsection{Ongoing development and improvements}

The plus-and-minus method represents a comprehensive and systematic tool for handling environmental impacts. It is open to discussion to which degree the un-priced environmental effects are taken into account in project decisions. Some would argue that the priced effects are given too much emphasis in decision-making, and that environmental concerns that are often left unpriced, are not given sufficient weight. However, the few existing Norwegian studies of this, suggest that road projects are not prioritized according to the benefit-cost ratio, and that "other" considerations are more important for decision makers (Odeck et al. 2015).

There is also some discussion about whether the current system for un-priced impacts are appropriate for use in cost-benefit analyses, as the system is based on expert judgment on how landscape, biodiversity, natural resources etc. are effected, and not so much on how the population's preferences are affected. This is illustrated by the complete opposite conclusions using the two methods in the case study reported here However, nobody has come up with an alternative system which is generally accepted.

Even if the final decision on which railway route to build is not yet made, we can already now say that this case study has raised awareness of the importance of also valuing welfare losses of ES impacts in monetary terms. We also observe a growing interest in Norway in incorporating the ES approach in natural resource management in order to assess projects with environmental impacts. There also seems to be a growing interest in the pricing of environmental impacts, which will support the assessment of welfare loss in ES impact assessments.

\subsection{On-shore wind power planning in Denmark}

\subsubsection{Current practice and values of landscape experience}

\section{Background}

The case we have selected in Denmark to exemplify how to include landscape experience values in EIAs was a project by the Municipality of Copenhagen to erect four large on-shore windmills in Kalvebod Syd, at the outskirts of Copenhagen (Københavns Kommune, 2011; Københavns Københavns Kommune, 2013; Københavns Kommune, 2011a). See Figure 4 for an overview. 


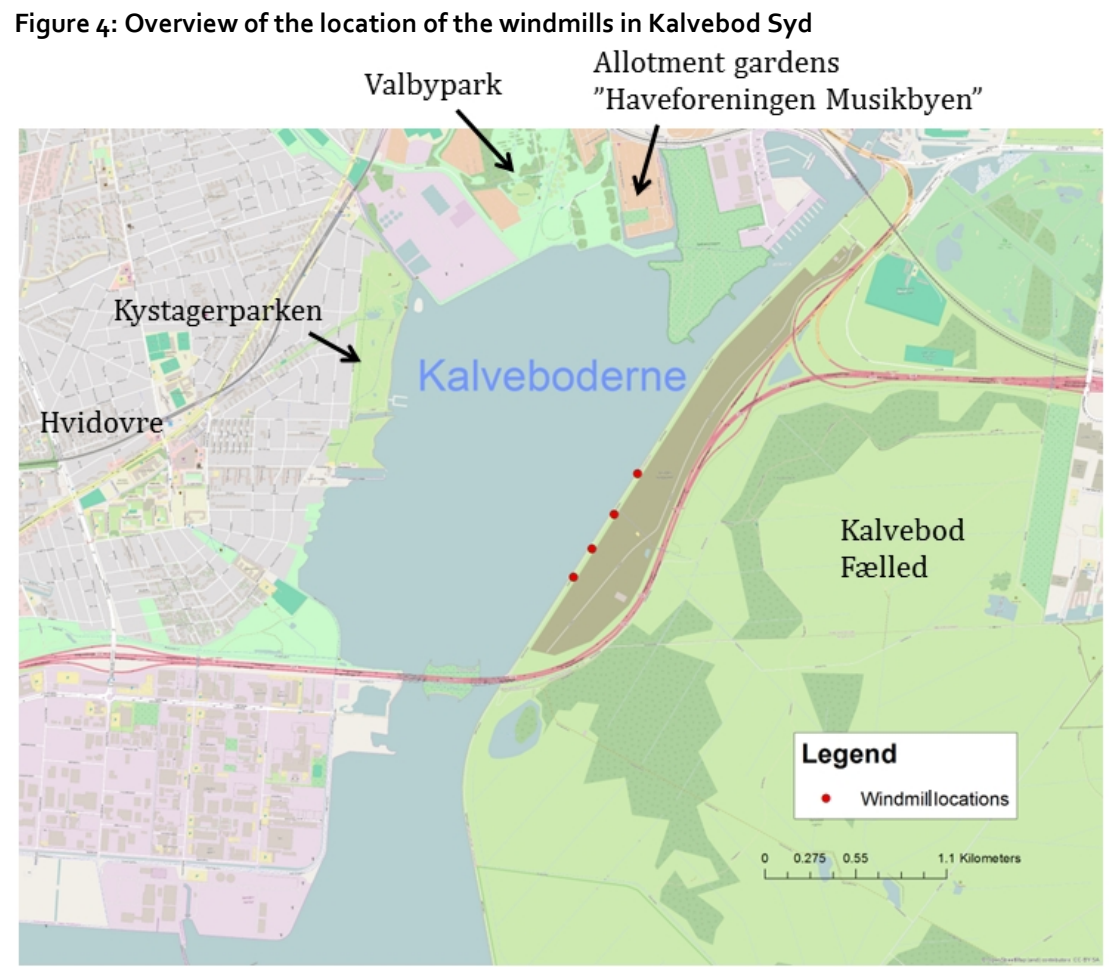

Source: OpenStreetMap contributors, CC BY-SA.

The height of the mills was planned for either $148 \mathrm{~m}$ or $120 \mathrm{~m}$ and placed $30-50 \mathrm{~m}$ from the coast, i.e. within the national coastal protection line. The location of the mills would also have been within a conservation zone (Kalvebodkilen) and close to Natura 2000 areas and protected marine area (Kalveboderne). In addition to the EIA, the location necessitated dispensation from the Nature Protection Act by the Nature Agency under the Danish EPA.

The EIA was sent in public consultation in 2013 with the conclusions that despite being dominating in the landscape from many angles and over long distances, the landscape is already disturbed and hence not a vulnerable landscape due to different types of technical installations in the vicinity. Technical installations close by and within a couple of kilometres include a recycling and depot centre, a motorway, large buildings further away in Ørestaden, the incineration plant Avedøreværket and existing windmills on Avedøre Holme ( $2 \mathrm{~km}$ away).

Today, some locations in the area have no visual impacts from the existing technical installations and would be impacted by the windmills, but according to the EIA, the expansion of the new neighbourhood Ørestad would over time become more and more dominating and hence reduce the visual impacts of the mills.

The impacts on the landscape (visual impacts) and recreational use (access was maintained) was thus deemed acceptable for the lifetime of the windmills ( 25 years) despite having a dominating impact. 
After a number of meetings, discussions and adjustments to the EIA, the Nature Agency gave dispensation from the coastal protection line with the argumentation i.a. that:

- landscape impacts are acceptable and the area is not vulnerable for additional technical installations

- access for recreation is not reduced

- the mills would be taken down after 25 years, which would also be the timing for closing down the recycling station and converting the whole area to recreation

- the mills would not entail damages to plants and animals under the Habitats Directive.

This would mean that the project could go ahead as planned.

Six organisations prepared complaints to the Nature and Environment Appeal Committee to reconsider the dispensation given by the Danish EPA. The complainants included three local communities along with the Municipality of Hvidovre, neighbouring the municipality of Copenhagen, and two environmental NGOs.

The Municipality of Hvidovre stated in the complaint:

- The windmills disturb the landscape and the landscape in the area is vulnerable.

- Kystagerparken on the west coast of the Kalveboderne and facing the project is the only large recreation site in the municipality and the EIA does not include visualisations of the project seen from the park.

- Find a professional lack of evidence that the Natura 2000 area would not be impacted.

The local resident associations complained that:

- The windmills would impact an undisturbed landscape, when seen from the west side of Kalveboderne. The dikes surrounding the motorway and the recycling/deposit centre are visual shields, such that the motorway and the recycling centre are shielded from their view. The windmills would therefore change an otherwise undisturbed landscape.

- Windmills of the proposed heights would be dominating up to a distance of $4.5 \mathrm{~km}$.

- The mills would cause substantial nuisance for recreation in the recreation areas around Kalveboderne, both visually and in terms of noise.

The environmental NGOs made i.a. following arguments:

- The mills would be a threat to birdlife, increasing risks of collisions and the conclusions regarding risk of displacement were based on older studies of smaller windmills. 
- The conclusion that the Natura 2000 site will not be negatively impacted was not based on best scientific evidence.

- The negative impacts on the landscape warrant a rejection. The landscape seen from Hvidovre is unique for citizens in that municipality.

The Nature and Environment Appeal Committee overruled the dispensation from the Nature Protection Act. The rejection was given on the grounds that the installation of the four large windmills would cause such a large change in conditions of the coastal areas around Kalveboderne and along the coast of the dammed protected areas of Vest Amager that this change would not be compatible with the significant landscape, nature and recreational values of these areas.

The landscape experience of Vestamager/Kalvebod is characterised by an interplay of nature and urban areas, where the nature area is open, flat and dammed, demarcated by a skyline of residential buildings, towers and technical facilities on the horizon, offering a contrast to the natural landscape. The existing technical facilities close to the area have only a limited impact on visibility due to canopy cover and a dike, shielding the view. The central location of four large windmill in the nature area was deemed by the Appeal Committee to be so dominant that they would cause a significant negative impact on the area. Further, the project would have a significant negative impact on the site, and on the majority of the surrounding continuous and open landscapes.

The EIA process and subsequent ruling by the Nature and Environment Appeal Committee exemplify how the risk of reducing cultural ES from a landscape experience can lead to a rejection of an energy project, and that a peri-urban/ urban landscape can be considered vulnerable and valuable enough to protect it. In our case demonstration, we intend to show how the inclusion of quantitative surveys and non-market valuation techniques can contribute to the insights of the scale of impacts that e.g. windmills may cause on the visual amenity and recreation values. In other words, we show that such information would make the basis for a decision such as the one above more solid.

\subsubsection{How could landscape values have been included?}

Level 1 - Screening

The EIA specifically mentions two areas of potential impacts relevant for the cultural services of landscape experiences in addition to noise impacts:

- impacts for neighbouring residents on the opposite side of Kalveboderne in Hvidovre. These impacts relate to changes in the aesthetic services of the landscape experience due to visual intrusions

- impacts on existing recreation areas and planned recreation areas. This relates to recreational services and how they may change (in quality and quantity) due to visual intrusion. Regarding planned recreation areas, the whole of the recycling \& deposit centre location will gradually be converted into recreational areas, 
starting in 2 years and with the last area converted after 25 years. This includes plans for allotment gardens and intensive recreational use.

Despite explicitly mentioning these two areas, the EIA does not include any evidence on users and local populations and therefore does not specify how many people and which type of groups of people may have their landscape experience impacted; how, when and how frequent they use the area etc.

The screening is used for identifying the most important cultural ecosystem services related to landscape experience that are taken forward in level two - the detailed assessment. Where data is missing, we indicate the type of information that would be necessary to include.

The first part of the screening is to identify the state, change and impacts of landscape experiences in terms of cultural ecosystem services (see Table 10). We base the screening on information readily available from the EIA documentation and the ruling of the Nature and Environmental Appeal Committee. As this is a different approach than in a traditional $\mathrm{EIA}$, some information is bound to be missing. 
Table 10: Identifying state, change and impacts of windmills in Kalvebod Syd, DK

\begin{tabular}{|c|c|c|c|}
\hline Cultural ES & $\begin{array}{l}\text { How much of the ecosystem service is } \\
\text { present before the change in landscape } \\
\text { (State indicator) }\end{array}$ & $\begin{array}{l}\text { Which functions }{ }^{*} \text { in the landscape will } \\
\text { be changed? (Change indicator) }\end{array}$ & $\begin{array}{l}\text { How many people will be impacted and } \\
\text { who are they? (Impact indicator) }\end{array}$ \\
\hline Recreational & $\begin{array}{l}\text { 1. "Kalvebod promenade" Bike/walk path } \\
\text { along the waterfront which would pass } \\
\text { under the windmills - one of the green } \\
\text { routes in Copenhagen connecting } \\
\text { Copenhagen and Kalveboden. } \\
\text { 2. "Kalvebod Fælled" - a large nature } \\
\text { and recreation site situated along the } \\
\text { project site, offering possibilities for } \\
\text { biking, running, skating and nature and } \\
\text { bird experiences. } \\
\text { 3. A number of path connections via } \\
\text { bridges towards other nature areas and } \\
\text { neighbourhoods in vicinity. } \\
\text { 4. "Kystagerparken" on the westcoast of } \\
\text { the water is the only large recreation } \\
\text { area in in the Municipality of Hvidovre } \\
\text { located across the water opposite the } \\
\text { proposed mills. }\end{array}$ & $\begin{array}{l}\text { 1. Access on Kalvebod promenade will } \\
\text { not be reduced, but passing close to the } \\
\text { windmills will create a very different } \\
\text { experience and disturb the recreation } \\
\text { experience. } \\
\text { 2. Landscape features of recreating in } \\
\text { "Kalvebod Fælled" will change } \\
\text { significantly and be disturbed visually } \\
\text { (and noise wise). } \\
\text { 3. Landscape features of passing through } \\
\text { and using the connections in the area will } \\
\text { change significantly and be disturbed } \\
\text { visually (and noise wise). } \\
\text { 4. Landscape features will change from } \\
\text { undisturbed landscape that is not } \\
\text { marked by technical installations to one } \\
\text { that is disturbed. }\end{array}$ & $\begin{array}{l}1,2,3 \& 4 \text {. No investigation made of } \\
\text { numbers of users, frequency of } \\
\text { visits/passing through, duration of use, or } \\
\text { type of users. } \\
1,2,3 \& 4 \text {. No surveys of perceptions and } \\
\text { attitudes of people doing recreation } \\
\text { regarding the proposed project. }\end{array}$ \\
\hline Aesthetic & $\begin{array}{l}\text { 1. "Kystagerparken" Hvidovre beach. } \\
\text { 2. Residential area. } \\
\text { 3. Allotment area close to Valbyparken. } \\
\text { Number/area of landscape features with } \\
\text { stated appreciation. }\end{array}$ & $\begin{array}{l}1,2, \& 3 . \text { Aesthetic quality of the } \\
\text { landscape will change significantly, } \\
\text { breaking up the view of greenness, } \\
\text { tranquillity and structural harmony. }\end{array}$ & $\begin{array}{l}\text { Ca. } 32,000 \text { households within } 4.5 \mathrm{~km} \\
\text { distance. No surveys of houses bordering } \\
\text { nature areas or number of people } \\
\text { enjoying the landscape aesthetics. }\end{array}$ \\
\hline $\begin{array}{l}\text { Natural } \\
\text { heritage }\end{array}$ & $\begin{array}{l}\text { Natura } 2000 \text { sites located immediately } \\
\text { west, south and east of project. } \\
\text { National protection areas inside project } \\
\text { area: beach meadow, water course; } \\
\text { protected presence of landscape } \\
\text { features with special educational and } \\
\text { scientific value/interest. } \\
3000 \text { ha protected nature areas on both } \\
\text { sides of the bay Kalveboderne, most of } \\
\text { which is public with open access. } \\
\text { Purpose of preservation was to maintain } \\
\text { and enhance an improvement of } \\
\text { biological and landscape values of the } \\
\text { area }\end{array}$ & $\begin{array}{l}\text { Vestamager is a designated Habitat and } \\
\text { Bird Protection Area of special } \\
\text { educational and scientific value/interest. } \\
\text { Important population of tufted duck, } \\
\text { with dwindling population. } \\
\text { No evidence from EIA of landscape } \\
\text { features or species with inspirational } \\
\text { value to human arts etc. } \\
\text { No evidence from EIA of landscape } \\
\text { features or species with spiritual and } \\
\text { religious value }\end{array}$ & $\begin{array}{l}\text { No indications in EIA on number of } \\
\text { school classes visiting, or number of } \\
\text { scientific studies etc. } \\
\text { No indications on number of books, } \\
\text { paintings, etc. using ecosystems as } \\
\text { inspiration. } \\
\text { No indications on number of people who } \\
\text { attach spiritual or religious significance } \\
\text { to ecosystems, but likely not important } \\
\text { as not pristine area. }\end{array}$ \\
\hline $\begin{array}{l}\text { Cultural } \\
\text { heritage and } \\
\text { identity }\end{array}$ & $\begin{array}{l}\text { Typical cultural landscape, created by } \\
\text { people as the area was dammed up in } \\
\text { the } 30-405 \text { and first used for agricultural } \\
\text { production, then as a military area and } \\
\text { since } 1984 \text { open for the public for } \\
\text { recreation. }\end{array}$ & $\begin{array}{l}\text { The flat, low-lying area characterized by } \\
\text { dikes with the sea higher than the } \\
\text { dammed up land. The location on the tall } \\
\text { mills on the dam would dominate the } \\
\text { cultural landscape }\end{array}$ & $\begin{array}{l}\text { No indication of number of people } \\
\text { "using" the landscape and area for } \\
\text { cultural heritage and identity. }\end{array}$ \\
\hline
\end{tabular}

Note: $\quad$ Ecological process and/or component providing the service or influencing its availability.

Source: Based on Københavns Kommune (2011a\&b, 2013), own GIS analysis.

The EIA describes the ex-ante landscape values and the impacts during and after implementation. Although the notion of ecosystem services is not applied, the present EIA report makes it generally possible to fill in for the state indicator (i.e. how much of the different ecosystem services is present before the proposed change) and the change indicator (i.e. which functions in the landscape may be changed after the proposed project is implemented). Information useful for the impact indicator, however, is found 
lacking in the EIA. This is due to the lack of surveys either directly asking people or observed data of users, residents, passers-by. Surveys can be used to assess the size and type of affected population, their attitudes and perceptions and to place economic values on the changes to the landscape experience.

Following the framework proposed in chapter 2, we next seek to:

- Score the changes likely to occur (see Table 11).

- Score the impacts for the relevant population (see 11).

- Assess the importance of a change in services to people, i.e. the welfare consequence based on the combination of the two abovementioned scores (see Table 12).

Table 11 scores changes and impacts using a ranking from no impacts or not relevant (score $=0$ ) to high impacts (score $=3$ ) for each of the cultural ecosystem services associated with landscape change. The scores are attributed based on the results of identifying and describing state, change and impacts (Table 10). For recreational services, we attribute a high score for both the degree of change on the landscape experience and the value or importance of avoiding that change to people. This high score is not in line with the EIA findings, but are based on the argumentation by the Municipality of Hvidovre and the residential associations in Hvidovre as well as the ruling of the Appeal Committee. The EIA did not make any surveys of potentially affected populations, which include local residents, passers-by and people visiting Valby Park. Also, the EIA did not make visualisations of visual impacts from the coast of Hvidovre Municipality or from Valby Park.

We attribute high importance of the landscape change to people living, recreating and passing by in the area based on the complaints i.a. by the municipality of Hvidovre stating that the "Kystagerparken" is the only large recreation area in the Municipality, from where there is an undisturbed view and one environmental NGO stating that recreation opportunities are reduced. Quantitative surveys indicating how the population and users of the area perceive the change could have provided such insights during the EIA phase. We also attribute high importance regarding both the degree of change and the importance to people of the aesthetic ecosystem service, i.e. the appreciation of the natural scenery other than deliberate recreational activities. This is based on arguments made by the residential associations. Again, surveys could have provided this insight during the EIA preparations.

For natural heritage services, e.g. excursions and field trips for educational or recreation purposes, we attribute a high ranking of the impact on the natural heritage based on the argumentation of the environmental NGOs. As we have no evidence of the extent to which people find this service important, we assign a low ranking, for sake of making an example of the method. Likewise, for cultural heritage and identity, as we do not find information of this in the EIA, complaints and rulings, we assign low values for both impact on the landscape and impact on people. 
Table 11: Scoring changes and impacts of Windmills in Kalvebod Syd, DK

$\begin{array}{lcr}\text { Cultural Ecosystem service } & \begin{array}{r}\text { Degree of change } \\ \text { (impact on landscape) }\end{array} & \begin{array}{r}\text { Importance/value to people } \\ \text { (impact on people) }\end{array} \\ \text { Recreational } & 3 & 3 \\ \text { Aesthetic } & 3 & 3 \\ \text { Natural heritage } & 3 & 1 \\ \text { Cultural heritage and identity } & 1 & 1\end{array}$

Note: Ranking: o-none; 1 -low; 2 -middle; 3 -high.

Based on the ranking for impacts on landscape and on landscape experiences for people, we follow the suggested template from Chapter 2 (see Table 12).

Table 12: Welfare consequence by cultural ecosystem service - case of windmills in Kalvebod Syd, DK

\begin{tabular}{|c|c|c|c|c|c|}
\hline & \multirow[b]{2}{*}{ Ranking } & \multicolumn{4}{|c|}{ Importance (value) to people } \\
\hline & & $0-$ not relevant in the area & 1 -low & 2 -middle & 3-high \\
\hline \multicolumn{6}{|l|}{ Recreational } \\
\hline Degree of impact & 3-high & o & 0 & -- & -- \\
\hline Aesthetic & & & & & \\
\hline Degree of impact & 3-high & 0 & 0 & -- & -- \\
\hline \multicolumn{6}{|l|}{ Natural heritage } \\
\hline Degree of impact & 2 -middle & 0 & - & 0 & o \\
\hline \multicolumn{6}{|c|}{ Cultural heritage \& identity } \\
\hline Degree of impact & $1-$ low & o & 0 & 0 & o \\
\hline
\end{tabular}

Ecosystem services that score $\mathrm{O}$ in Table 12 are omitted from level 2- detailed assessment, as they have been found to have no or little importance. We retain services that score higher than zero because they may have a large importance to the population when combined.

From the EIA documentation, it becomes clear that people potentially affected by the project have not had the opportunity to evaluate impacts. Also, no survey of observed behaviour was undertaken to substantiate the impacts on residents, passers-by and recreationists or quantifications of how many people may be affected and how much.

Level 2 - Detailed Assessment

The detailed assessment aims to quantify in monetary or in non-monetary terms the changes in welfare to people affected by the change in landscape experiences. This is carried out for the most important cultural ecosystem services identified in level 1 , which in this case include the aesthetic, recreational and natural heritage services.

\section{Aesthetic services}

Aesthetic appreciation of the landscape, other than the deliberate recreational use, can be assessed using the hedonic pricing method (HPM). This method traces the impact through property price decreases. Please refer to chapter 2 for a brief description of the method. We apply a benefit transfer from a Danish study using HPM of the impact of 
noise and visual pollution from wind turbines (Jensen et al., 2014). Box 1 summarises the study.

\section{Box 1: Valuing the impacts of noise and visual pollution from wind turbines in Denmark}

This study investigated the impacts of near-by land based windmills on property prices in 24 locations across Denmark. Using a dataset of 12,640 traded residential properties sold in the period from 2000 to 2011 and located within 2,500 metres of a windmill, they managed to separate the welfare effects of noise and visual pollution caused by windmills.

Visual pollution was modelled by constructing view sheds with digital surface models, enabling the authors to identify properties where wind turbines are visible. About one third of the houses in the analysis were found to have a view of a windmill.

Results show that wind turbines have a significant negative impact on prices of neighbouring residential properties. Visual pollution reduces on average the residential sales price by up to 3 percent and noise pollution by between 3 percent and 7 percent, depending on the noise level.

Average marginal willingness to pay (WTP) for avoiding to have a view of a nearby windmill is estimated at EUR 6,233 per residence while the marginal WTP to avoid the view of a windmill increases with proximity of the wind turbine at a rate of $479 \mathrm{EUR} /$ residence for each 100 meter the property is closer to a windmill, compared to a distance of $2,500 \mathrm{~m}$.

Source: Jensen et al. (2014)

In the case of the windmills at Kalvebod Syd, we identify the number of residential buildings in bands of 100 meters from the turbines and up to $4.5 \mathrm{~km}$, which in EIAs are considered as the near-zone. Residential properties were identified using the Danish Registry of Building and housing Database (BBR).

If time permitted, one could calculate the number of properties which have a view to the turbines following the same methodology of Jensen et al. (2014). We assume for simplicity that the same share of properties have a view of the wind turbines as in the study by Jensen et al. (2014), i.e. 33 percent.

We multiply the average marginal WTP of avoiding to have a view to a windmill (EUR 6,233) with one third of the total number of households ( $\mathrm{N}=2313$ ) (Item (3) in Table 13. This results in a negative welfare effect of EUR 4.7 Mio (Item (4)). When taking into account that views to the wind turbines at shorter distance are valued higher (in negative terms) than when located further away, the negative welfare effect for one third of the households within 2,500 $\mathrm{m}$ of the wind turbines would amount to ca. EUR 72.2 Mio (Item (5)). ${ }^{7}$ This welfare effect is assumed to take effect at the beginning of the project lifetime of the windmills. The EIA states a life time of 25 years of the project. When the mills are removed (and supposing no new generation of windmills are installed) the house prices would presumably increase again, all other things equal.

7 We assume in this case that value changes occur immediately as the project starts. Hence, the values are already present values. Once the windmills are removed after 25 years, the house prices would presumably rise again. As we do not estimate welfare changes after the project lifetime, we do not consider this aspect. 
The welfare effects are in this case produced for illustrative purposes. A more thorough benefit transfer is recommended in an EIA (or CBA) process, for instance assessing via Geographic Information System (GIS), the number of properties that have a view shed to the windmills, instead of assuming as we do here, the same share of properties with a view as in the primary study.

Table 13: Benefit transfer elements - Windmills in Kalvebod Syd, DK

\# Item Values

$\begin{array}{llr}\text { (1) View (average MWTP) } & 6,233\end{array}$

(2) View X Distance (per 100 m) (average MWTP) 479

(3) Total number of households within 2500m from turbines $\quad 2,313$

(4) Negative welfare effects of having a view (33\% of properties) [(1) X (3) X 0.33] (EUR) $\quad 4,757,587$

(5) Negative welfare effects: view $x$ distance to turbines (33\% of properties) [(2) $x$ distance to wind $\quad 72,204,765$ mills $\times$ [number of properties per $100 \mathrm{~m}$ ] $\times 0.33$ ]

\section{Recreational services}

We have assigned a double minus on the potential impact of the project on recreational services in the area to signify the importance of the impact (see Table 12).

The introduction of the tall windmills in an otherwise (relatively) undisturbed landscape would significantly disturb the landscape experience and hence reduce the recreational benefits or welfare that people derive from walking, jogging, playing and sailing in the area. How much welfare would be reduced depends on:

- the number and frequency of people recreating

- the availability of substitute sites

- the marginal utility change due to the (potential) introduction of the windmills per person or household.

This would necessitate a survey of recreational use and a measure of unit value, either from a primary valuation study of the area or from a benefit transfer of a study investigating the same type of change under similar conditions. Valuation studies of changes in recreational services include the travel cost method, contingent valuation and choice experiments (See Chapter 2.2.4 for an overview).

Existing valuation studies on windmills in Denmark to date have been based either on changes in property values (Jensen et al. 2014) or valuation of off-shore windmills (See e.g. Ladenburg 2009; Ladenburg and Dubgaard 2007) and hence no national studies would in this case be applicable for a benefit transfer.

International benefit transfers are possible if conditions and the change evaluated are similar and if values are adjusted to national purchasing power levels. To our knowledge, however, none of the existing valuation studies on wind power in Northern Europe specifically investigate impacts on recreation values (see e.g. Meyerhoff et al., 2010 for an overview). This may be the case because wind turbines are most often sought placed away from intensive recreation areas and not in the middle of them. 
Natural heritage

In this demonstration case, we have assigned a single minus on the welfare consequences on natural heritage services if the four windmills were to be erected (see Table 12).

Natural heritage as a cultural ecosystem service in relation to landscape refers to presence of landscape features with special educational and scientific interest, or with an inspirational, spiritual and religious value. Indicators of the value of natural heritage could be number of school classes visiting the area, or number of scientific studies, books, and paintings that use the area or find inspiration from it directly or indirectly.

We recommend that for this type of ecosystem service, field studies of use and attitudes along with a mapping of the cultural significance based on text studies is conducted in order to ascertain the impact of the project. The field studies could be partially combined with quantitative surveys of the local population and user groups needed to evaluate recreation impacts. In our case here, no such information is available.

\subsubsection{Effects and lessons}

The assessment of landscape impacts in the EIA does not specifically make use of the ecosystem services approach. Some aspects of the EIA assessment are, however, directly applicable for describing the state (i.e. how much of the different ecosystem services is present before the proposed change) and change indicators (i.e. which functions in the landscape may be changed after the proposed project is implemented) for at least some of the cultural ecosystem services (recreational and aesthetic appreciation).

The EIA does not, however, contain information that allows for an evaluation of impact indicators for different groups of people affected: local residents, owners of allotment gardens, passers-by on the several by cycling and promenading pathways and people recreating on the water of Kalveboderne and in the large recreational areas surrounding Kalveboderne. Because the location is in the middle of a large recreational and urban area, it makes sense to investigate the scale and importance of impacts on people. This could be covered by carrying out surveys or field investigations to assess the size and type of affected population, their attitudes and perceptions, and also to place economic values on the changes to the landscape experience.

The ecosystem services approach is essentially a people-based approach. By integrating the ecosystem services framework in EIAs, more emphasis can be placed on understanding the impacts and importance for local people and to provide the case for introducing more participatory approaches or at least surveying affected populations. The need for including the voice of people is also underpinned in the European Landscape Convention, which states that landscape is an area, as perceived by people, whose character is the result of the action and interaction of natural and/or human factors (European Landscape Convention \$1). 
If more information on the different categories of affected population and the ecosystem services that they derive from the landscape experience were included in EIAs, such as this example, they could ideally be applied in an economic valuation framework, such as CBAs.

Our conclusion is that integrating an ecosystem services approach to EIAs can introduce new and more nuanced tools to assess impacts on landscape experiences. It brings in a user perspective of the everyday landscape experience that can complement the current expert-based approach. Mels and Mels (2014) in a report in Sweden on landscape analyses, in connection with wind power planning, recommend a move towards involving people and their views to complement the traditional expert and civil-servant based and administratively led landscape assessment.

The use of monetary valuation studies can provide insights into some, but not all, of the welfare changes likely to occur. The use of benefit transfer from existing monetary studies or carrying out a new study of course is operational but necessitates insights and experience with using the different types of valuation methods. This is a specialized field just like in the case of landscape assessment or ecological assessments in EIAs. In the present case, we illustrate in a crude fashion how a benefit transfer could be carried out to assess the scale of welfare impacts on residential homes. A more detailed benefit transfer could be possible, e.g. by assessing the number of properties with a view shed to the wind turbines using Geographic Information System (GIS). In the present case, we have assumed an average based on the primary study. We find a substantial negative welfare effect for households within 2,500 $\mathrm{m}$, with an average of 4.8 Mio EUR across all households and as much as EUR 72.2 Mio, when taking into account that distance matters.

With regards to cultural heritage and identity it seems we need to primarily rely on non-monetized valuation in the form of qualitative assessments, based on user group studies as well as texts (laws, cultural products etc.).

In this demonstration case, the proposal to establish four large wind turbines in Kalvebod Syd was stopped through the ruling of the Nature and Environment Appeal Committee. This is a relatively rare case. In other EIAs, the inclusion of ecosystem based approaches and monetary and non-monetary valuation of the impacts of people's welfare can help improve the decision basis and may contribute to adjust plans and mitigate impacts in important ways that would otherwise not have been found. A complete assessment of welfare impacts of the windmills would of course need to look at other costs and benefits of the mills, not just the landscape impacts. 


\subsection{Off-shore wind power planning in Finland}

\subsubsection{Current practice and values of landscape experience}

Background

At the end of 2015 the Finnish wind power capacity was 1005 MW produced by 387 generators. Wind power supplied $2.8 \%$ of the Finnish electricity production in 2015 (FWPA). The planned capacity is roughly 10 times the current capacity and could influence the landscape of more than 700,000 residences. ${ }^{8}$

The most valuable Finnish landscapes have been preserved by law and are protected from construction projects that could influence the landscape. Regionally important landscapes are designated by a government decree (Ministry of Environment 1995, 2014), which brings them under the shelter of the environmental protection act (Luonnonsuojelulaki (1096/1996)) and environmental impact assessment (EIA) procedure (Laki ympäristövaikutusten arviointimenettelystä 10.6.1994/468), which both consider landscapes.

The Finnish governance system allows several stakeholders to be heard in the legislative and planning processes. Thus, it is possible for people to state their preferences concerning laws and larger projects that could influence the value of landscapes. However, the citizens' preferences are filtered through either the political representative or an administrative hearing. Therefore the legislation and planning might not accurately reflect the aggregate value that people derive from landscapes.

The value of landscape is open to interpretation in different contexts. While the existing legislation and political strategies demonstrate that landscapes clearly carry some value, they offer very limited information that could be used to quantify the economic welfare effects of landscape changes. There are currently no peer reviewed studies in Finland that have assessed the effects of wind power on landscape in monetary terms. Kosenius and Ollikainen (2013) show that wind power is the favourite renewable energy source for the Finnish people, but the study does not include landscape effects as an attribute of the different types of energy production. Janhunen et al. (2014) study attitudes towards wind power among second home owners and locals, but do not elicit economic values nor focus on landscape impacts.

\subsubsection{The Siipyy offshore wind farm case}

The Siipyy wind power development project illustrates how landscape values are currently integrated in wind power development planning in Finland. Furthermore, we demonstrate how monetary valuation methods could be used to support the decisionmaking process for Siipyy.

\footnotetext{
${ }^{8}$ Own analysis based on the number of residential housing within a $30 \mathrm{~km}$ buffer of current and planned wind power capacity from www.tuulivoimayhdistys.fi/en
} 
The goal of the Siipyy project was to build a maximum of 80 windmills, with a planned capacity of $400 \mathrm{MW}$, nearby the Siipyy village and the town of Kristinestad on the west coast of Finland (See Figure 5).

Figure 5: Map showing the location of the planned Siipyy wind power project off the Finnish west coast

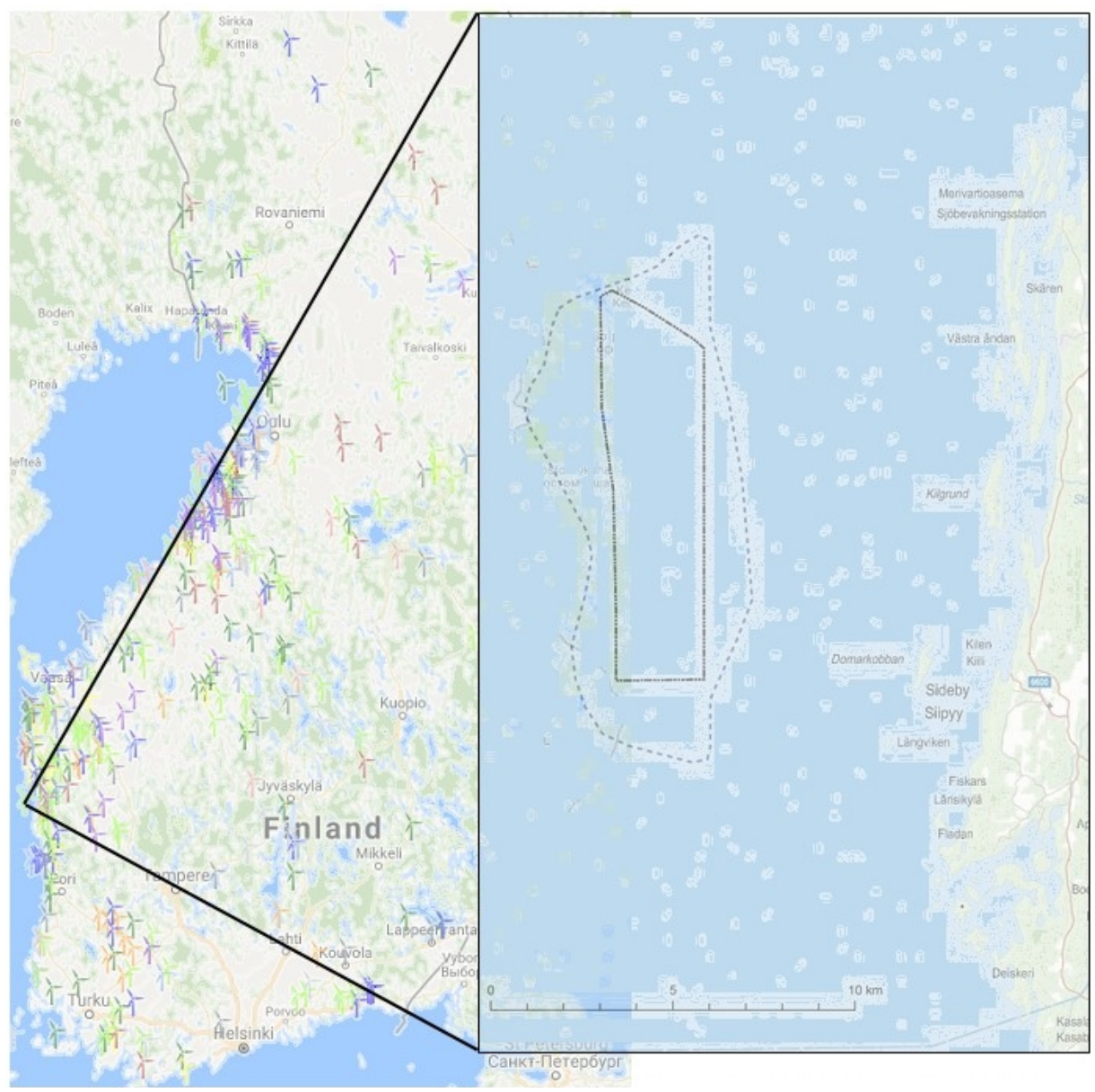

Note: The landscape plan is drawn with a solid black line, while the proposed project at the Environmental Impact assessment (EIA) stage is drawn with the dotted line (Ramboll Finland Oy 2009). Pls. refer to http://ethawind.com/map/ for details on the colours of wind mill symbols (Ethawind 2016)).

This case is particularly interesting since the wind park was planned on a shallow coastal area that had been designated for offshore wind power development in the landscape plan (Pohjanmaan maakuntakaava 2030, Ostrobothnia Regional Council, 2008). The location of the wind park had previously been approved by the regional authorities, but was nevertheless rejected in the local plan, which overrides the regional plan. The question is whether valuation methods could have provided data to convince the local decision-makers that the welfare loss from the impacts on the natural scenery would be small; or, if the welfare loss was large, could valuation lead to modifications of the landscape plan? 
The EIA of the Siipyy project (Ramboll Finland Oy 2009) does not provide estimates of the value of the landscape impact. However, it does contain the typical visualisations and map-based impact areas. Compared to EIAs of some smaller projects, the Siipyy EIA contains a more thorough evaluation of landscape impacts and a residential household survey ( $\mathrm{N}=276$ households returning the survey corresponding to a $28 \%$ response rate). Compared to some more recent EIAs of wind farm projects, the Siipyy EIA contains less information about the locations from which the windmills would be visible i.e. view sheds produced with GIS. The information about the landscape impact presented in the EIA was interpreted differently by the majority of the city council compared to the project's landscape experts.

The Siipyy EIA states that the evaluated impacts of the project on culturally important landscapes are not remarkable. However, the EIA also recognizes that the visual effects of the proposed wind park would be clear, as seen from the nearby village with nationally noted scenic values affected. This type of contradiction can be found also in EIAs of other wind power projects, and carries the message that despite the undeniable impact on landscape, this is not an obstacle for the project as perceived by the project consultant. Furthermore, to support the positive image of the project, the EIA highlights current impacts on the landscape from existing developments, the general inevitable trend of changing landscapes, and people's capability of adapting their preference to accept these changes. Regarding the impacts on landscape, the EIA is focused on permanent residences and summer housing. However, the report omits information on the actual number of homes and summer cottages and the distances from the project site. Fishing and other recreational boating are mentioned, but little effort has gone into quantifying the recreational activities, or identifying the ones most vulnerable to scenic quality changes. The residential household survey carried out as part of the EIA asks for activity frequencies for several types of recreation relevant for landscape, as well as a broad range of attitudes towards wind power and the Siipyy project.

In the responses to the EIA, the board of the municipality of Kristinestad considers unanimously the EIA to be sufficient. However, the environmental administration of the same municipality presents a much more critical evaluation in its own statement, including terms such as "irreversible damage to unique landscape". The EIA was approved by the regional authorities (22.9.2010), but with requests, for example for a more thorough investigation of landscape impacts. During and after the EIA, the municipality proceeded with developing a more detailed plan (started in 1.10.2009) (Kautto and Söderholm 2015). This plan was prepared by the same consulting company that did the EIA. This clearly shows how the municipal level plans (yleiskaava/osayleiskaava), even though approved by the municipality, are drafted by the development consultants. Due to the opposition of local decision makers the plan did not move forward despite the EIA being approved in the board of the city council. In 2012, Suomen Merituuli Oy calls for the Ministry of Environment to order the municipality to proceed with local plan in accordance of the regional plan, but the Ministry refuses to enforce the regional plan it has approved. Based on the municipal level plan of 2012, which was not approved, the development consultants formulate a 
new version of the plan which locates the wind park slightly further from the coast. On September 2015, the city council of Kristinestad rejects this new version of the plan for Siipyy (18 versus 9 votes) (Pohjalainen 2015).

The project still exists in the portfolio of Suomen Merituuli Oy. However, a EUR 20 M grant by the Ministry of Employment and Economy for the offshore demonstration plants applied for by Suomen Merituuli Oy in 2014, has been granted to another wind power developer in a different region. This further decreases the attractiveness of the project, and following the current government's plans to reduce the feed-in tariff to the wind energy sector in 2015 (Helsingin Sanomat 2015) the project seems to have no future.

\subsubsection{How could landscape values have been included?}

Level 1 - Screening

The EIA documentation records several types of activities that may be impacted by the wind power project. These can be categorised into cultural ecosystem services and used for identifying the state, change and impacts on landscape experiences. Cultural heritage is represented by the nationally dedicated landscape areas and places of cultural interest, both of which can be found within the visible range of the project. Landscape impacts are considered most important for Secondary homes, while the influence on primary residential housing is assessed to be more limited due to limited view sheds and greater distance. The nearest village is roughly 10 kilometres away and the town of Kristinestad $20 \mathrm{~km}$ away.

The EIA mentions activities related to the harbour, fishing, cycling near the coast and boating, but it does not quantify the number of users nor estimate negative welfare effects. The EIA considers tourists to be less negatively impacted by the project due to the limited time of exposure. In addition, the EIA indicates that the wind power plants may offer potentially scenic elements of value for tourists. Table 14 gives an overview of the different cultural ecosystem services, indicators of how much of the ecosystem services are present before the potential alterations to the landscape (state indicator); the type of functions that may be impacted (change indicator) and the level of impact on residents and tourists (impact indicator). 
Table 14: Identifying state, change and impacts of Windmills offshore from Siipyy vil-lage, Finland

\begin{tabular}{|c|c|c|c|}
\hline $\begin{array}{l}\text { Cultural } \\
\text { ecosystem } \\
\text { service }\end{array}$ & $\begin{array}{l}\text { How much of the ecosystem } \\
\text { service is present before the } \\
\text { change in landscape } \\
\text { (State indicator) }\end{array}$ & $\begin{array}{l}\text { Which functions in the } \\
\text { landscape will be changed? } \\
\text { (Change indicator) }\end{array}$ & $\begin{array}{l}\text { How many people will be impacted, } \\
\text { and who are they? } \\
\text { (Impact indicator) }\end{array}$ \\
\hline Recreational & $\begin{array}{l}\text { 1. Coastal road used for cycling } \\
\text { and walking within visible } \\
\text { distance. } \\
\text { 2. Fishing. } \\
\text { 3. Boating. } \\
\text { 4. Outdoor activities, winter. } \\
\text { 5. Outdoor activities, summer. } \\
\text { 6. Bird and "other nature" } \\
\text { watching. } \\
\text { 7. Holidays in the archipelago. }\end{array}$ & $\begin{array}{l}1,4,5,7 \text { No functional } \\
\text { change, but activities could } \\
\text { change. } \\
\text { 2. Potential changes due to } \\
\text { impacts on fish spawning } \\
\text { areas. } \\
\text { 3. Major lanes not blocked, } \\
\text { but use restrictions to the } \\
\text { project area. } \\
\text { 6. Potential change in } \\
\text { population of rare species } \\
\text { and migration route. Direct } \\
\text { impact on landscape. }\end{array}$ & $\begin{array}{l}\text { No investigation made in duration of } \\
\text { visits/passing through, duration of use. } \\
\text { Frequencies and types of activities } \\
\text { surveyed based on the local population in } \\
\text { the resident survey. (Tourists without } \\
\text { second homes not included). } \\
\text { Survey in perceptions and attitudes } \\
\text { towards the proposed project. } \\
\text { Assessment of impact on landscape in } \\
\text { general (not by the activity categories) } \\
\text { (See Box 2). }\end{array}$ \\
\hline Aesthetic & $\begin{array}{l}\text { 1. Bird and nature watching sites. } \\
\text { 2. Permanent residences. } \\
\text { 3. Seasonal residences. }\end{array}$ & $\begin{array}{l}1, \& 2 \text { Aesthetics of the } \\
\text { landscape will change. }\end{array}$ & $\begin{array}{l}\text { Survey (as above) is based on postal } \\
\text { codes. Indicates } 552 \text { households within } \\
\text { the closest village's postal code areas. }\end{array}$ \\
\hline $\begin{array}{l}\text { Natural } \\
\text { heritage }\end{array}$ & $\begin{array}{l}\text { 1 Natura20oo sites located within } \\
20 \mathrm{~km} \text {. } \\
\text { 2. Bird and nature watching. } \\
\text { 3. Bird species migrating by. }\end{array}$ & $\begin{array}{l}\text { No evidence from EIA of } \\
\text { landscape features or } \\
\text { species with inspirational } \\
\text { value to human arts etc. } \\
\text { No evidence from EIA of } \\
\text { landscape features or } \\
\text { species with spiritual and } \\
\text { religious value. }\end{array}$ & $\begin{array}{l}\text { No indications in EIA on number of school } \\
\text { classes visiting, or number of scientific } \\
\text { studies, books, paintings using } \\
\text { ecosystems as inspiration etc. } \\
\text { No indications of number of people who } \\
\text { attach spiritual or religious significance to } \\
\text { ecosystems. }\end{array}$ \\
\hline $\begin{array}{l}\text { Cultural } \\
\text { heritage and } \\
\text { identity }\end{array}$ & $\begin{array}{l}\text { Sites nominated for landscape } \\
\text { value a) nationally b) regionally. } \\
\text { Cultural heritage sites. }\end{array}$ & $\begin{array}{l}\text { No direct impact on the } \\
\text { number of sites. Aesthetic } \\
\text { impacts not quantified. }\end{array}$ & Survey as above. \\
\hline
\end{tabular}

Note: Based on the Siipyy EIA (Ramboll Finland Oy 2009).

As can be seen from the impact categories, it is difficult to avoid a certain level of overlap between the different ecosystem services and their indicators. The EIA includes many relevant activities for cultural ecosystem services, but quantified data for the state, impact or value are not provided as such.

While the majority of respondents in the household survey did not perceive the landscape effects of the project as negative, the majority of the respondents did perceive that the project had an effect on their landscape ranging from completely tolerable to completely intolerable.

The majority of respondents considered the coastal area as important to them, but as the household survey did not operate within an ecosystem services framework, we cannot directly attribute importance levels from the survey to specific ecosystem services, such as the importance of landscape while recreating. Only $21 \%$ of the respondents in the residence survey, living within the influence of existing windmills, considered the proposed wind power project to be a reduction in environmental and living standards. However, the impact on the sub-sample of respondents, who considered the landscape impact as intolerable, could be significant. Interestingly, although $42 \%$ of respondents considered the project to have negative or very negative 
impacts on the landscape, more than half of respondents, even those with a view to the project area, preferred some construction option over the no construction option.

The EIA concludes that none of the cultural ecosystem services that are related to landscape experience would be significantly reduced by the project. The EIA also concludes that no significant impacts on valuable landscapes would occur. This seems to be mainly based on limited or no visibility from the local cultural heritage site and the lack of visibility from the nationally designated landscape protection areas further away.

The results of the EIA were questioned by the local environmental authorities and ultimately by the city council. Vagueness of the data incorporated in the EIA on the landscape impact leaves a lot of room for contestable value statements that could have been better weighted with more efforts spent on gathering (and publishing) numerical data on usage of different ecosystem services and perceptions of impacts.

Table 15 scores changes and impacts using a ranking from no impacts or not relevant $($ score $=0$ ) to high impacts $($ score $=3$ ) for each of the cultural ecosystem services related to landscape experience. The scores are attributed based on the results from Table 14 on identifying and describing state, change and impacts.

For aesthetic services, i.e. the appreciation of the natural scenery other than deliberate recreational activities, we attribute a medium score for the degree of change on the landscape experience and a high score on the value or importance of avoiding that to people. This is based on the survey conducted as part of the EIA, where the majority of people who stated they would have a view to the project area considered landscape effects to be negative or very negative.

For recreational services, we attribute a medium score for both the degree of change on the landscape experience and the value or importance of avoiding that change to people. This score is not based on findings from the EIA, as it did not provide a full survey on the extent of recreational use of the area with a view to the offshore wind park. Only little effort went into quantifying the recreational activities and identifying the people most vulnerable to scenic quality changes. We attribute a medium score here for illustrative purposes.

For natural heritage we attribute a low score on both degree of impact on landscape and impact on people based on the EIA, while cultural heritage and identity scored medium on impact on people given the importance of the regional cultural heritage sites. As with recreation, the EIA did not provide sufficient quantification or identification on what the changes in landscape experiences would impact on cultural heritage. Again, we score for illustrative purposes.

Box 2: Local survey of perceptions and attitudes towards the Siipyy offshore wind farm

As part of the EIA, a local survey was conducted to assess perceptions and attitudes towards the proposed project ( $\mathrm{N}=276 ; 28 \%$ response rate). The survey focused on households with either temporary or permanent residence in postal codes of the nearby villages and town of Kristinestad. According to the resident survey, $13 \%$ of respondents go fishing at the coast on a weekly basis, while $8 \%$ on a monthly basis and $20 \%$ at least once a year. $25 \%$ go fishing on a rare occasion. Recreational fishing is a common activity in the region: $75 \%$ of respondents in a local survey of boat owners ( $N=58$ 
households which had on average 2.9 recreational anglers and people doing recreational net fishing) had been fishing at the coast off Siipyy, indicating that a lot of the local fishing happens within the visible range of the proposed wind park. The actual intended park area is not used for recreational fishing hence the impact on recreational fishing would mainly be due to the change in landscape aesthetics. The catches were mainly perch, pike, and common bream; while the biggest impact of the proposed project on fish may have been on herring, since it is spawning in the type of habitats of the proposed wind park. Furthermore, windmills can also create a "reef effect" in which the foundations provide a sheltered habitat for fish, and this could offset the damage done to fish populations during the construction phase. Despite such compensatory effects, $36 \%$ of the respondents in the household survey considered the project to have a negative or very negative impact on fishing. It is not clear from the EIA survey, how large a role landscape plays in the recreational angling and fishing activity of the respondents.

Other recreational activities in the coastal region also frequently benefit the respondents. The most frequent activity comprise enjoying the sea and the aesthetics of the coastal landscape, which more than $50 \%$ of respondents reported doing at least monthly. Boating and other recreational activities during summer, bird and nature watching, as well as holidays in the archipelago were listed as weekly activities by more than $20 \%$ of respondents. The impacts of the project on recreational activities were less often considered to be negative or very negative, compared to the direct impact on fishing or the landscape which $42 \%$ considered to be negative or very negative.

In summary, the majority of the surveyed residents did not consider the project to have negative impacts on recreational activities, while the respondents with a view of the project area $(\mathrm{N}=70$, as identified based on address) responded on average more negatively.

Table 15: Scoring changes and impacts of windmills in Siipyy, Finland

$\begin{array}{lcr}\text { Cultural Ecosystem service } & \begin{array}{r}\text { Degree of change } \\ \text { (impact on landscape) }\end{array} & \begin{array}{r}\text { Importance/value to people } \\ \text { (impact on people) }\end{array} \\ \text { Recreational } & 2 & 2 \\ \text { Aesthetic } & 2 & 3 \\ \text { Natural heritage } & 1 & 1 \\ \text { Cultural heritage and identity } & 1 & 2\end{array}$

Note: Ranking: o-none; 1 -low; 2 - medium; 3 -high.

Based on the ranking for impacts on landscape and on landscape experiences for people, we follow the template from Table 6 . 
Table 16: Welfare consequence by cultural ecosystem service - case of offshore wind-mills in Siipyy, Finland

\begin{tabular}{|c|c|c|c|c|c|}
\hline & \multirow[b]{2}{*}{ Ranking } & \multicolumn{4}{|c|}{ Importance (value) to people } \\
\hline & & $\begin{array}{r}0-\text { not relevant in } \\
\text { the area }\end{array}$ & 1-low & 2-middle & 3-high \\
\hline \multicolumn{6}{|l|}{ Recreational } \\
\hline Degree of impact & $1-$ low & o & o & - & -- \\
\hline \multicolumn{6}{|l|}{ Aesthetic } \\
\hline Degree of impact & $1-$ low & o & o & - & \\
\hline \multicolumn{6}{|l|}{ Natural heritage } \\
\hline Degree of impact & $1-$ low & o & o & o & \\
\hline \multicolumn{6}{|c|}{ Cultural heritage \& identity } \\
\hline Degree of impact & $1-$ low & 0 & 0 & 0 & \\
\hline
\end{tabular}

Ecosystem services that score 0 in Table 16 are omitted from the level 2 detailed assessment, as they have been found to have no or little importance when combining the degree of impact and the importance of that impact to people. We retain aesthetic and recreational services for the detailed assessment.

Level 2 - Detailed Assessment

The detailed assessment aims to quantify in monetary or in non-monetary terms the changes in welfare to people affected by the change in landscape experiences. This is carried out for the most important cultural ecosystem services identified in level 1, which in this case include the aesthetic, recreational and cultural heritage services.

The EIA unfortunately provides no information on the importance of tourism, the frequency of visit, the duration of their stays or their attitudes towards the proposed project. This is problematic since the cultural heritage site is an active tourism destination, but the association running the museum and other activities does not publish the visitor numbers and its museum is not listed in the national registry. ${ }^{9}$ Without further studies, the value of landscape for tourism cannot be thoroughly understood, but some overall idea of preferences of tourists can be formulated based on the surveyed attitudes of local people, who for a destination such Siipyy, are also likely to represent a significant part of visitors. Box 2 summarises the results of the local survey undertaken as part of the EIA.

The majority of people who stated they would have a view to the project area $(\mathrm{N}=40 ; 14 \%$ of sample) considered landscape effects to be negative or very negative. This indicates that, the welfare change for this group could be particularly important. Unlike in some more recent EIAs, the number of the affected households within predefined distance bands from the park location was not published as a part of the EIA.

\footnotetext{
${ }_{9}^{9}$ As a reference point, the largest museum in the province has roughly 15000 visitors annually, while Kilen Hembygård is open only from June to August, smaller and harder to reach from cities. An estimate of 3000 visitors annually would likely be an overestimate.
} 
Own analysis of distances between the proposed project and residential buildings are summarized in Table 17. The analysis is based on a manually digitalised project map and may contain some errors compared to the original official documentation.

Table 17: Residential buildings in the proximity of the Siipyy wind park project

Distance from the project $(\mathrm{km})$

\begin{tabular}{|c|c|c|c|c|c|}
\hline & 2.5 & 5 & 10 & 15 & 20 \\
\hline Permanent residences & 0 & 0 & 343 & 405 & 1081 \\
\hline Holiday housing & 0 & 3 & 631 & 465 & 750 \\
\hline Total & 0 & 3 & 974 & 870 & 1831 \\
\hline
\end{tabular}

Based on the findings in Table 17, the number of residential buildings is higher than what could be expected, when reading the EIA. Even if only a third of the buildings within the distance categories would be with an actual view of the project area, the actual numbers would seem to collide with the EIA statement of no significant impact.

Moreover, the landscape effect in the EIA was considered to exist, but it was not regarded as significant due to a distance of $8 \mathrm{~km}$ between the project area and the residences. As acknowledged in landscape literature regarding windmills (for example Bishop, 2002) and even in the Siipyy EIA in its earlier sub-chapters, the windmills can be seen from a distance up to $30 \mathrm{~km}$, depending on the conditions, so the conclusions regarding the impact in Siipyy seem to be poorly founded.

We use the available data on number of residences as a basis for a benefit transfer of residents' willingness to pay to have the wind farm located further ashore, thus reducing the visual disamenities (Ladenburg et Dubgaard, 2007). Box 3 summarises the primary study to be used in the benefit transfer. In the case of Siipyy, we carry out a simple unit value transfer taking the identified the number of residences within a band of $20 \mathrm{~km}$ from the proposed wind farm and the income weighted WTP values per household from Ladenburg and Dubgaard (2007).

Box 3: Valuing the reduction of visual disamenities of offshore wind farms in Denmark

Ladenburg \& Dubgaard (2007) investigated how much people in Denmark would be willing to pay (WTP) to reduce the visual disamenities of future off-shore wind farms by placing them at larger distances from the coast. The WTP was elicited through choice experiments.

The valuation scenarios comprised of a potential location of 720 offshore wind-mills (equivalent of $3600 \mathrm{MW}$ ) in farms at distances equal to 12,18 or $50 \mathrm{~km}$ from the shore, relative to an $8 \mathrm{~km}$ baseline, with visualisations of how this might look like. At the largest distance, the windmills would be invisible from the shore, and out of the sight of typical coastal activities.

700 Danes were randomly selected to participate in the mail survey and asked to select the most advantageous combination of additional annual payments on top of the electricity bill, increased distance of future wind farm from the coast and the size of the wind farm.

Income weighted results show that respondents are willing to pay 33, 94, and 107 EUR/household per year for locating offshore wind farms at 12,18 or $50 \mathrm{~km}$, respectively. If only respondents with a view of the coast were included, the WTP would increase to $280,422,468$ EUR/households/year for 
having future wind farms sited at 12,18 and $50 \mathrm{~km}$ respectively. Results also indicate that the benefits of placing wind farms further than $18 \mathrm{~km}$ from the coast are negligible.

We apply two types of welfare values, based on the primary study: a lower willingness to pay per household for the population in general and a higher willingness to pay per household for those who in the EIA residence survey stated they would have a view to the project area.

A more thorough analysis investigating view sheds would provide more accurate data on the number of residences with a view. For the purpose of illustrating the principle of introducing welfare estimates to EIAs, this is sufficient.

Table 18 presents the elements in the benefit transfer and the total welfare values of reducing disamenities by moving the proposed wind farm further away from the coast compared to $8 \mathrm{~km}$.

Table 18: Benefit Transfer Elements - Siipyy wind power project, Finland

\begin{tabular}{|c|c|c|c|c|}
\hline \multirow{2}{*}{$\begin{array}{l}\text { Distance from } \\
\text { coast }\end{array}$} & \multicolumn{2}{|c|}{ General population } & \multicolumn{2}{|c|}{ Respondents with a view to the coast } \\
\hline & EUR/household/year a & EUR/year ${ }^{b}$ & EUR/household/year ${ }^{\text {a }}$ & EUR/year ${ }^{b}$ \\
\hline $12 \mathrm{~km}$ & 47 & 86,057 & 280 & 74,301 \\
\hline $18 \mathrm{~km}$ & 98 & 179,438 & 422 & 111,983 \\
\hline $50 \mathrm{~km}$ & 125 & 228,875 & 468 & 124,190 \\
\hline
\end{tabular}

Note: Number of residences (within $20 \mathrm{~km}$ distance from project) ${ }^{\mathrm{b}}: 1,831$.

Number of residences with a view to the project area $(14 \%)^{\mathrm{b}}: 265$.

Source: ${ }^{\mathrm{a}}$ Ladenburg and Dubgaard (2007), weighted unit values; ${ }^{\mathrm{b}}$ Own calculations.

Results of the simple benefit transfer indicate a relatively high utility of reducing visual disamenities for a minority of residences with a view to the coast. Based on the EIA data, we identify 265 residences with a view to the project area ( $14 \%$ of the EIA sample). Moving the proposed wind park $12 \mathrm{~km}$ ashore compared to $8 \mathrm{~km}$ from the coast is valued at more than EUR 74,000 per year, while a $18 \mathrm{~km}$ distance from coast to wind park would be worth EUR 112,000 per year to people with a view. A $50 \mathrm{~km}$ distance to the coast would not bring substantial additional welfare to residents compared to a distance of $18 \mathrm{~km}$. Given the substantial costs of moving wind farms further away from the electricity grid, this is an interesting piece of information.

If instead we apply the unit values for the general residential population, we obtain welfare levels at EUR 86,000 for $12 \mathrm{~km}$ distance compared to $8 \mathrm{~km}$ distance, increasing up to close to EUR 230,000 if moved to a $50 \mathrm{~km}$ distance. The two values should not be added, however, to avoid double counting.

In summary, based on a benefit transfer from Denmark, we find substantial annual welfare benefits of reducing visual disamenities of the offshore wind farm for residents. These values do not take into account the amenity impacts of people using the landscape for recreation purposes at the coast and at sea. 
These values only cover the aesthetic impacts for local residents, not tourists visiting the area. Also welfare effects from impacts on recreation due to changes in landscape experiences are not covered by this valuation approach. Please refer to Chapter 3.2.2. Recreational services for details on valuation of changes in recreation services.

\subsubsection{Effects and lessons}

As in the previous Danish case of wind power impact assessment, the EIA does not specifically make use of the ecosystem services approach. Details and surveys from the EIA make it generally possible, at least to some extent, to describe the state (i.e. how much of the different ecosystem services is present before the proposed change) and change indicators (i.e. which functions in the landscape may be changed after the proposed project is implemented). However, information useful for the impact indicator (how many people will be impacted and who are they) is found somewhat lacking: no investigation was made on the duration of use and duration of passing and only the local resident population was surveyed, not tourists or the importance for the local cultural heritage site. Due to the lack of information on impacts for the recreation and cultural and natural heritage services, we could not illustrate welfare impacts through a value transfer.

The valuation of the aesthetic disamenities potentially resulting from the project ranges from EUR 86,000 to EUR 230,000 depending on the distance from the shore. This does not cover the full welfare losses of changes in the landscape. Comparing welfare impacts on aesthetic landscape experiences with the climate benefits of the wind power park shows clearly a balance towards establishing the park. The proposed project would have cost EUR $400 \mathrm{M}$ and the project benefits from just the $\mathrm{CO}_{2}$ reductions at the EU carbon market would be between EUR 2.5 M (with the historically low price of EUR $5 / \mathrm{tCO}_{2}$ ) and EUR $35 \mathrm{M}$ if using the social costs of carbon estimates for example from the European Commission (Morris 2016; Watkiss et al. 2005).

From these numbers, it is fairly clear that the environmental benefits of the project would have outweighed damages caused to the landscape amenities. Even if the tourists' perceived loss of value would be equal to that perceived by locals, the conclusion would not change. For a EUR $400 \mathrm{M}$ project like the Siipyy wind power park, however, the added costs of up to EUR 230000 to compensate the locals could be substantial.

In the past literature on wind power, the involvement of local community has been identified as an important factor for successful project implementation (Jobert et al. 2007; Mason and Milbourne 2014; Bush and Hoagland 2016; Zaunbrecher and Ziefle 2016). In the case of Siipyy, the City Council of Kristinestad did not perceive any economic benefits to the municipality and rejected the project (Pohjalainen 2015).

Convincing the residents and local decision-makers on the societal net benefits of planned projects could be also irrelevant for the project success. The Not In My Back Yard (NIMBY) is a widely reported phenomenon relevant for wind power, which is generally supported by the people who refuse to support it locally. The economic or environmental benefits of wind power might not be reaped by the local people. 
Particularly, the offshore developments do not generate income streams for local land owners. From the Siipyy project, the economic benefits would have been directed to the company Merituuli and its shareholder such as the City of Helsinki. For locals, the property tax was estimated to bring a couple of hundred thousand annually, which is in par with the upper bound of the landscape damage estimates. Therefore, even the local net benefits of the project could have been positive. The question still is, if this information would have made a difference in the local decision-making. According to the residence survey $87 \%$ of respondents (and even $63 \%$ of people identified with a view) supported the construction.

The proposed procedure for establishing landscape values based on the cultural ecosystem services could have been used to involve the locals more and to collect direct data on the perceived losses of value from the residents. Compared to the standard EIA procedure in Finland, the method involving valuation and CBA requires more data on behaviour such as recreational activities and tourism, as well as produces estimates of environmental costs that can be compared with benefits using money as a common unit of measurement. However, also the standard EIAs made in Finland on wind power include surveys, which serve the same goal of involving the local community in the decision-making process. Including ecosystem service approaches and valuation methods can clearly contribute to inform decision-makers and be a substantial factor in CBAs to include otherwise non-prices welfare effects.

\subsection{Other case studies}

In the last section of this chapter we include three other case studies, which we describe in less detail:

- Road planning in Norway.

- Road planning in Denmark.

- Energy projects in Iceland.

In the in-depth cases, we followed the step-by-step method or approach outlined in chapter 2, while the shorter cases we present here illustrate different aspects of including landscape values in assessments and planning processes.

\subsubsection{Road planning in Norway}

In chapter 3.1 we described briefly the methodology used at present for incorporating environmental impacts, including impacts on landscape in the guidelines for costbenefit analysis in NPRA. The environmental impacts are assessed using a nonmonetary valuation method, called the "plus-and-minus"-method (called the "consequence fan"-method in NPRA 2014). 
In Box 4 in this chapter, we describe briefly an attempt to value in monetary terms the landscape impacts of alternative routes for a road project in south eastern Norway (Alsvik 2013). The study is a Master thesis, but the contingent valuation survey was funded by the Norwegian Public Road Administration as a pilot study to assess the possibility of including monetary unit values for landscape impacts in their CBA/EIA manual (i.e. the current $V_{712}$ manual).

The case demonstrates that people had different willingness to pay for different road alternatives, some of which were due to different landscape impacts.

\section{Box 4: Economic valuation of landscape impacts from a road project in Norway}

Introduction to case

The case study discusses development and building of a new national highway - RV 4 - in Nittedal local community, close to Oslo. Several alternative routes for the new highway were assessed, and the study presents three alternatives, called A, B and C. The welfare loss of the landscape impacts is estimated in a new contingent valuation (CV) study as the affected households' willingness-to-pay (WTP) (from a payment card) in order to get each of the new routes and their specified landscape impacts instead of the existing road. The affected population was assumed to be the local community Nittedal, (nearly 9, ooo households), and the sample size for the survey collecting the population's WTP was 166.

\section{Cultural ecosystem services in landscape valued}

The $V_{712}$ manual for non-priced assessment of environmental impacts include five environmental impacts (see chapter 3.1). According to our simplified list of relevant cultural ecosystem services connected to landscape (see Table 3 in chapter 2 ) several of these would be included in the landscape ecosystem services. In this case study, however, the emphasis was on the impact called "landscape/aesthetic effects", and the author aimed to include only the visual aspects of landscape experience in the valuation study. However, the author notes that elements of WTP for related environmental impacts are probably included in the WTP estimates for landscape/aesthetic effects.

Value assessment

The survey concludes that there is a positive WTP for all alternatives, compared to the existing road. Total WTP for alternative A was ca. NOK 10.6 million, for alternative B ca. NOK 11.4 million and for alternative $\mathrm{C}$ ca. NOK 13.3 million.

\section{Lessons learned}

The present value of WTP for avoiding environmental costs due to landscape aesthetic impacts increased the net benefits of all these alternative routes. However, the ranking of alternatives was not changed by including them in the CBA in this case. One experience from the valuation study carried out for this project is that it was difficult to value landscape aesthetics separately from other environmental impacts of the road project. Thus, the values probably include more environmental aspects, according to the author. In order to include valuation of all the environmental impacts listed in $\mathrm{V}_{712}$ in the $\mathrm{CBA}$, one must be aware of the risk of double counting. An ecosystem services approach may be helpful in this respect, in sorting out the services received from different environmental impacts and describing how they can be affected by the road project, (like we did in chapter 2 in this report).

Source: Alsvik (2013) 


\subsubsection{Road planning in Denmark}

CBA is an integrated part of the impact assessment process of roads, railways and other large infrastructure projects in Denmark (Trafikministeriet 2003). Externalities relating to road projects, such as changes in air pollution in inner cities, time savings and fewer traffic fatalities are valued in monetary terms.

However, according to the Danish Ministry of Transport and Energy, landscape is one of the aspects along with recreation, groundwater, nature and wildlife, and regional distributional impacts that CBA should explicitly not quantify as these impacts are deemed too complex to incorporate in CBAs. Instead, these impacts should be taken into account through qualitative measures only, e.g. by using a 5 point scale for the level of impact.

By not valuing nature and landscape impacts in the same metric as other externalities and market-based costs and benefits of road infrastructure projects, there's a risk that CBAs provide misleading results because the assessment of social costs and benefits is incomplete.

An ES approach in valuing landscape impacts can help structuring and clarifying the type of values that can be assessed quantitatively. We describe how in Box 5.

Box 5: Economic valuation of landscape disamenities of motor-way construction in Denmark

Introduction to case

The case study concerns quantifying preferences for protecting different types of landscapes from road encroachment when building new motorways in Denmark.

Recognising that excluding impacts on nature and landscapes may potentially lead to false conclusions, Olsen et al. (2005) sought to illustrate how to include public preferences for changes to landscapes in CBAs with the aim to widen the scope of welfare economic assessments of motorway projects.

A Contingent Valuation survey was carried out for a sample of respondents living in the Silkeborg area, using an Open-Ended elicitation format and a Double Bounded Dichotomous Choice. 1000 postal questionnaires were sent out in each of the formats with an effective response rate of ca. $71 \%$. The town of Silkeborg is home to approximately 90,000 people.

Cultural ecosystem services in landscape valued

The cultural ecosystem services valued with respect to landscape amenities include the aesthetics of appreciating a beautiful landscape and recreation. The valuation study investigates two different proposed routes/layouts of the motorway: 1 ) the Resendal layout north of Silkeborg, which would intersect a 1,400 ha large preserved nature area in the Gundenå valley; and 2) the Ringvej layout that would pass through the town of Silkeborg. Both layouts would affect landscape aesthetics and recreation, but in the Ringvej lay out, other determinants were also of importance including noise, pollution and barrier effects to people living in the town. In the Resendal area it is predominantly the landscape aesthetics of a remarkable river valley at stake whereas the Ringvej layout would affect mainly recreational services from an urban forest.

Value assessment

Results showed that faced with the choice of the two proposed layouts for the Silkeborg motorway, $76 \%$ of the respondents prefer the Resendal layout whereas only $24 \%$ prefer the Ringvej layout. To ensure realisation of the preferred layout, those preferring the Resendal layout are on average willing 
to pay DKK 1,318 per household per year, while those preferring the Ringvej are willing to pay DKK 1,428. People in and around Silkeborg would on average prefer a lay out that would cut through the protected nature area rather than intersect and move through the town.

Lessons learned

In addition to obtaining a monetary value for the preferred motorway layout, which could be included in the CBA of the road project, the study also helps to understand what are significant determinants of welfare when preferring one layout over another. People preferring the layout option of Resendal, which negatively impacts a scenic landscape, but leaves the centre of Silkeborg town intact, tend on average to earn a higher income, be concerned about the impacts on the centre of Silkeborg, have more frequent visits to the recreational site that would be impacted by the alternative lay out and to disagree that motorways negatively impact on landscape.

People preferring the layout option of the Ringvej, which would leave a scenic landscape intact, tend on average to have a higher income, be older than the average sample, live in the countryside, and be more concerned about the consequences for animals and plants.

According to Danmarks Naturfredningsforening, Vilstrup conducted a national survey in 2006, asking 1002 Danes whether they would prefer a motorway layout going through a business zone or through a protected nature area. The vast majority, 82 percent, stated they preferred the first option.

In 2006, the Danish Government decided upon a combination of the two layouts: the motoway should not cut through the protected nature area of Resendal, but instead move through a business zone of Silkeborg and cross the recreational area of Nordskoven. To the east of the town, the motorway would follow the Resendal line and avoid the inner town. The motorway was inaugurated in what was called "Denmark's largest road party" in September 2016.

Source: Olsen et al. (2005), DN (2006).

\subsubsection{Energy projects in Iceland}

Decision-making in Iceland has occurred without reference to economic valuation of the environmental impacts of energy projects (Cook et al. 2016). ElAs have played an important role in identifying environmental impacts of energy projects since 1994, and in proposing mitigation measures. This is like in the other Nordic countries. However, the information in the EIA is not sufficient to provide necessary information about the welfare impacts, and it is difficult to compare with other costs and benefits of the projects.

Box 6 reflects a discussion by Cook et al. (2016) on the need and usefulness of economic valuation methods to count environmental impacts, including the landscape impacts, of energy projects in Iceland monetary terms. The most important projects with significant impacts are hydropower projects, though Iceland also has some geothermal energy. 
Box 6: The case for using economic valuation methods to assess impacts of energy projects in Iceland

Introduction to case

Hydropower and geothermal energy provides almost 100 percent of electricity generation and 85 percent of primary energy use in Iceland. No effort has been made to date to quantify the environmental impacts in monetary term to be compared with the economic gains of the projects.

\section{Cultural ecosystem services and value assessment}

In an Icelandic context, Cook et al. (2016) notes that the potential non-use value associated with preserving potential hydropower and geothermal sites may represent a considerable proportion of total economic value, especially for any future energy projects relying on hydropower resources located in the nation's remote and uninhabited central highland region. They further note the challenge of finding the right population affected by such impacts. Some sites, such as the future geothermal projects of Hverahlí and Eldvörp, also have potential recreation value that will be reduced. In Iceland, like in other Nordic countries, the knowledge of visitor numbers and distribution is low and often will need to be collected, for example in a travel cost survey.

Cook et al. (2016) mention a particular case where they argue that economic valuation of environmental impact could have been important, and that it was not weaknesses of the EIA process that led to what they think probably was the wrong decision, from a welfare perspective. There was a heated debate concerning the environmental impacts of the 690 MW Karahnjukar Hydropower plant in eastern Iceland, the largest such project in Iceland since 2007. The purpose was to provide electricity for a large aluminium smelter. The impacts were predicted to be long-lasting and severe, diminishing both landscape value of the area and biodiversity. Many of the impacts were considered irreversible. This case was not subject of economic valuation of landscape and other impacts, where such information may have been useful for the decision of approval or not.

The authors mention a few other previous valuation studies in Iceland where willingness to pay to prevent environmental impacts was estimated (e.g. hydropower projects in Skagafjordur and Karahnjukar) (see Lienhoop and MacMillan 2007). Lienhoop and MacMillan (2007) estimated people's willingness to accept (WTA) compensation for reduction in wilderness and landscape qualities associated with the hydropower development at Karahnjukar. A new deliberative group-based approach to contingent valuation, called the market stall approach, was applied to achieve this as it provides members of the public the opportunity to discuss and learn about the environmental change, to consult with family and friends, and to reconsider their WTA. Mean WTA was estimated at about EUR 62 per household per year at the time. However, the results were not used in decision-making, to our knowledge.

Lessons learned

Cook et al. (2016) offer a few concluding observations. Using the total economic valuation framework, they describe (including the ecosystem service approach; and both use and non-use values) can be a very effective means of identifying the specific ecosystem services providing environmental benefits to society. They mention two upcoming CV surveys on the geothermal areas of Hverahlið and Eldvörp that can serve as an illustration of a carefully conceived methodology that could be applied to a future Icelandic energy project. Many of these are set to occur in remote areas where a significant proportion of their total economic value may derive from non-use value. In all cases, however, it is necessary for project-specific consideration to be given to identifying the most suitable non-market valuation technique(s) for estimating the environmental benefits set to be sacrificed.

Source: Cook et al. (2016). 


\section{Discussion and recommendations}

In this final chapter we first synthesize some general lessons from the use of our suggested method to assess and value landscape experiences and some potential improvements. Then we outline some recommendations for further integration and work to assess, value and incorporate impacts on landscape experiences in practice.

\subsection{Lessons from applying our suggested stepwise method}

In this report, we have suggested a step-wise method for using the ES approach to assess and, to the extent possible, value landscape impacts. The method can be applied in environmental impact assessments (EIAs) and cost-benefit analyses (CBAs) to help incorporate and quantify people's preferences and views. The method was split into a level 1 "screening" and a level 2 "detailed assessment".

\subsubsection{Screening level}

The screening level served to determine the level of impacts that a given infrastructure or construction project may have on the different cultural ESs associated with landscape experiences. For each identified ES, descriptions and quantifications need to be made of the state of the ES, the change that would occur with the project and the impact that the project would have in terms of how many people would be negatively affected and who they are.

Although none of the EIAs from the in-depth cases applied the ES framework, they do include information on the state and type of change to the landscape that could be attributed to the different ESs. The cases all found, however, that it would have been a clear advantage to make the screening by individual ESs, as this would ensure that all relevant parts of potentially impacted populations would be covered in the EIA. For instance, in the Norwegian case, the EIA was at a strategic level, which does not include exact details of alternative routings or number and distances of affected households. In the Danish case, the EIA included substantial visualisations of the impacts, but omitted to make the visualisations from the angle of the population who would be the most significantly impacted in terms of recreation and aesthetic services. Finally, in the Finnish case, the households with a view to the project area were not identified and the EIA was lacking in the attempts of quantifying impacts on tourism.

The EIA cases generally appear to be lacking in quantifying the size of the impact, including the size of the population affected. This is crucial for aggregating the impacts and for ensuring that all relevant parts of the affected population are included in the assessment. In all EIA cases, only little information was available about who would be 
affected by the proposed project. This included information on i) how many would actually experience reduced possibilities or quality in recreation services and landscape aesthetics; ii) locations of recreation sites and residents with a view shed to the proposed project; iii) which alternatives (or substitutes) they would have to compensate for the visual disamenities with regard to recreation and aesthetic services; and iv) how many actually hold values for natural and cultural heritage.

The Finnish EIA case was the only one to conduct a household survey in the local area, which provided valuable knowledge on perceptions and use of the area. Unfortunately, the EIA did not include quantifications from the survey, and it was not possible to attribute the importance of the different ESs to local people, as the ES framework is not yet applied in this field. The ElA did not study the importance of tourism, the frequency of visit, the duration of their stays or their attitudes towards the proposed project.

Surveys such as the one conducted in the Finnish EIA could be extended to accommodate an ES framework, which could help ensure that all landscape experience impacts are included and that all the relevant groups of people are considered.

The scoring of degree of changes, the scoring of impacts on people depend and the subsequent ranking of plusses and minuses in terms of welfare consequences depend on the level and quality of information available. In the Danish and Finnish cases we could not make a fully robust scoring, given the caveats described above, but it was sufficient to show how the method can be utilised. This serves to make a comprehensive overview of the likely level of impacts and to decide whether or not to proceed to a more detailed assessment level. This two-step approach serves to eliminate unnecessary investigation, but on a solid basis, and to focus the detailed assessment.

The Danish and Finnish ElAs appeared to be similar in the way in which the consultants carrying out the EIAs arrived at conclusions that were not necessarily backed-up by surveys and solid data. If future EIAs were to include an ES approach and a two-step method or similar suggested in this report, we would ensure a far more detailed level of information that is based on people's actual use and preferences for landscape experiences. Expert judgements are important, but not always sufficient, and can help create better EIA processes.

The strategic level EIA from Norway did not include quantified information on affected populations and the size of impacts. While this level of information definitely ought to be gathered and assessed at project level EIAs, it would be an advantage to also have at least pilot level information on population and their perceptions of impacts at the more strategic level. It is at this level, where for example routings of a road or railway have not yet been decided, where such information may make the biggest difference to people's welfare.

\subsubsection{Detailed assessment level}

We have focused on applying monetary valuation approaches in the cases to show how quantifying impacts on landscape experiences can be done in practice. The applications of value transfers from the literature necessitates a minimum of information on the size 
of impact for the different ESs, the size of the affected population and what role alternatives could play for the different groups of people. This type of information could be gathered and prepared during the screening level. The value transfers also necessitate that adequate primary studies (study sites) are available that are comparable in population composition and type and scale of impact.

In all three in-depth cases, we did not have information on how many people would in practice have their view sheds affected. This can be conducted using GIS analysis or through surveys during the screening phase. Instead, we made assumptions to illustrate how the method could be applied. There was also a lack of good primary studies to transfer from, at least in the Norwegian and Finnish cases. Even so, the value information provided gave ballpark estimates of welfare impacts that are certainly more useful than no such information at all.

\subsubsection{Overall conclusion}

Our simple stepwise method has provided a first way to think about how landscape experiences can better be assessed in the analysis of public infrastructure projects with potentially large landscape impacts. The case studies have shown that even if information is sometimes lacking, the method makes an improvement over the current practice by helping in making public decisions stand on a firmer, more people-based footing. This means that the decision basis can be made more robust and about the key issue; how the affected people see the landscape impacts through their own eyes, so to speak.

\subsection{Further work and integration of landscape experiences}

The European Landscape Convention emphasises an obligation to ensure the participation of the public in the definition and implementation of landscape policies and it also requires countries having ratified the convention to establish necessary procedures to achieve this. This necessarily means, as we have argued both in NCM (2015) and this follow-on phase that people's preferences for landscape experiences need to count (more) in policy processes with significant landscape impacts, either due to the scale of impact or due to the vulnerability of the existing landscape.

Some of the big landscape-changing decisions are taken at a level above the project based EIA level, for instance the national planning for wind power, transmission lines or motorway projects. At semi-strategic level (e.g. KVU in Norway) and at EIA project levels, there is limited scope for doing much else than choosing a slightly different routing of a pre-determined road project, or transmission line section etc. - or to abandon the project altogether, as happened in the Danish and Finnish cases described in this report.

EIA procedures already entail an assessment of landscape impacts, which is carried out by professionals, and once the EIA has been developed, public hearing phases are an integral part of the decision-making process. However, no explicit requirements are currently part of EIAs to involve people and their views to complement the expert 
assessments. Mels and Mels (2014) recommend in a report in Sweden on landscape analyses about wind power planning a move towards involving people and their views to complement the traditional expert and civil-servant based and administratively led landscape assessment.

This is very much in line with the thinking of economics and the basis for the ES approach (and cost-benefit analysis), which we advocate in this report. The ES approach is essentially a people-based approach, which can introduce new and more nuanced tools to assess landscape experience impacts to help understanding the importance of impacts for people. The ES approach provides the case for introducing more participatory approaches or at least surveys of affected groups of people.

Depending on the type of ecosystem services that are in play, different valuation approaches are available, be they monetary or non-monetary. Common for them are an investigation of people's preferences and usages of the landscape. Mapping and assessing landscape experience impacts may quickly become complex and lead to the definition of a number of user groups. In order to be able to do valuation in an effective manner, it is limited how extensively one can do user group studies. Still, it should be possible to map main user groups and use questionnaires with representative selections.

When applying monetary valuation methods to gain insights into the importance of landscape changes, the impact is measured in unit value of the landscape experience, times the number of people affected by the landscape change. For "everyday" landscapes close to urban centres, the total impact may be much larger than for more remote landscapes. However, for iconic remote landscapes, people also hold non-use values, which ought to be considered as well. These may in many cases be quite large (cf. public discussion of the Hardanger power line on the west coast of Norway). Even if the valuations of people's preferences not necessarily change the decision on a given project, they may contribute to adjust plans and mitigate impacts in important ways. It should be noted too, that people are good to adapt and may (increasingly) prefer landscapes with human modifications rather than "protected areas" in their neighbourhoods. This means that it will also be important to understand people's preferences over time.

\subsubsection{Considerations for further work and integration}

We offer some points to consider with regard to further assessing landscape impacts:

- Of the cultural ESs related to landscape experiences, recreation and aesthetic services lend themselves more easily to quantitative monetary valuations. With regards to cultural heritage $\&$ sense of place it is more appropriate to primarily rely on valuation in the form of qualitative assessments, based on user group studies as well as texts (laws, cultural products etc.). New deliberate group-based approaches can also be applied that combine monetary and qualitative investigations (re. example from Iceland in Box 6). There are also other nonmonetary approaches discussed in the literature. 
- Comprehensive surveys among people who are likely to be affected by changes in the different ESs related to landscape experience should be carried out. Such surveys can also include monetary valuation questions or at least provide the necessary information needed to conduct proper value transfers. In all cases we have looked at, the number and frequency of users and uses of areas affected have not been surveyed.

- There is a dire lack of monetary valuation studies applied to landscape impacts and landscape experiences. In this study, we could find no applicable primary surveys from Finland to use for the value transfer; only one from Denmark was applicable. We found no applicable landscape valuation studies related to infrastructure projects in. The studies from Norway were few and relatively old. As value transfers cannot be better than the primary study, it's a prerequisite to have high quality valuation studies that represent the range and scale of landscape changes as well as the representativeness of populations and different user groups. But the ideal is that primary valuation studies are carried out for infrastructure projects of a certain size and impact. Alternatively, a generic study could be conducted covering typical landscape impacts from infrastructure projects, that later could be used for transfer to the relevant assessments in need of value estimates. ${ }^{10}$

- If a primary valuation study is not carried out, the alternative is value transfer. When transferring value information from the literature, a challenge to date, is that existing primary studies often do not apply an ecosystem services approach or assess landscape impacts as such. We therefore to some degree need to translate and interpret the primary study objects within the ES approach.

- Assembling a Nordic/European database of assessments and valuations of landscape impacts for people could be useful for valuing landscape changes in EIAs and similar assessments. New primary studies ought to include ample information sufficient to be able to use them for future value tranfers (information of state, impact and population).

\subsubsection{Next steps?}

The step-wise method we have suggested here is only a first attempt to move the concept of landscape experiences to practical assessment. A next step would be to refine and further develop this method, and possibly test it on more and on other cases that could include other sectors, project types, including perhaps also the higher strategic levels of decision-making. At the higher strategic level, detailed information of impacts are usually not available as exact locations, routings etc. have not yet been decided. There is still a great need for welfare-relevant information for decision-makers at this level. Where to locate wind parks along the Norwegian coast, for example,

${ }^{10}$ This is the approach chosen by for example the Norwegian Coastal Authorities and the Public Roads Administration (though covering other impacts than landscape impacts). See e.g. Vista Analyse (2016). 
should not be considered project by project only. They need to be considered together. Valuation studies may also be useful at this level, where for example alternative national plans can be put before a national, representative sample for their judgement.

Once the method has been refined and tested further, there is a need, as we have discussed above, to preferably commission more primarily valuation studies of landscape impacts. These can be supplemented by assembling a database of existing studies from the Nordic and European countries as basis for value transfer (work we also started with NCM (2015)). The method is only a framework that needs to be populated with more information about both impacts in physical terms (including number of people etc.) and the value of impacts. Without such information, it is difficult to get the full potential from the method.

If the method is considered a step further for practical assessment of landscape experiences, and ecosystem services more generally, incorporating the method into existing or new guidelines for EIA and CBA would be a natural final step. Only through including this thinking in existing guidelines, will the practices, and hopefully the resulting public decisions on the basis of this improved information, change for the better for Nordic landscapes. 


\section{References}

Alsvik, K. (2013). Samfunnsøkonomisk verdi av landskapsinngrep ved veiprosjekter - en Betinget Verdsettingsstudie. Economic value of landscape intervention by road projects- a contingent valuation study. Master Thesis. Norwegian University of Life Sciences.

Act on Environmental Impact Assessment Procedure - Laki ympäristövaikutusten arviointimenettelystä 10.6.1994/468.

Atkins and Metroeconomica (2013). Applying an Ecosystem Services Framework to Transport Appraisal. Final report. Utarbeidet for Department for Transport, Storbritannia.

Ayala, de. A. et al. (2014). Transferring landscape values using discrete choice experiments: Is meta-analysis an option? Working paper, European Society for Environmental and Resource Economists.

Bishop, I. (2002). Determination of thresholds of visual impact: the case of wind turbines. Environment and Planning B: Planning and Design. 29, 707-718. https://doi.org/10.1068/b12854

Bush, B. and Hoagland, P. (2016). Public opinion and the environmental, economic and aesthetic impacts of offshore wind. Ocean \& Coastal Management. 120, 70-79.

https://doi.org/10.1016/j.ocecoaman.2015.11.018

Cook, D. et al. (2016). Energy projects in Iceland - Advancing the case for the use of economic valuation techniques to eval-uate environmental impacts. Energy Policy 94:104-113.

https://doi.org/10.1016/j.enpol.2016.03.044

COWI (2016): KVU Grenlandsbanen. Delrapport ikke-prissatte virkninger.

Czajkowski, M., A. Bartczak, M. Giergiczny, S. Navrud and T. Zylicz (2014): Providing preference-based support for forest ecosystem service management. Forest Policy and Economics 39; 1-12. https://doi.org/10.1016/j.forpol.2013.11.002

Daniel, T.C,., Muhar, A., Arnbeger, A., Aznar, O., Boyd, J.W., Chan, K.M.A., Costanza, R., Elmquist, T., Flint, C.G., Gobster, P.H., Gret-Regamey, A., Lave, R., Muhar, S., Penker, M., Ribe, R.G., Scauppenlehner, T., Sikor, T., Soloviy, I., Spierenburg, M., Taczanowska, K., Tam, J., von der Dunk, A. et al. (2012). Contributions of cultural services to the ecosystem services agenda, Proceedings of the National Academy of Sciences of the United States of America 109(23): 8812-8819. https://doi.org/10.1073/pnas.1114773109

de Groot, R.S., Alkemade, R., Braat, L., Hein, L., Willemen, L et al. (2010). Challenges in integrating the concept of ecosystem services and values in landscape planning, management and decision making. Ecological Complexity 7, pp. 260-271.

https://doi.org/10.1016/j.ecocom.2009.10.006

DN (2006). Beskyt Gudenådalen mod motorvejen [Protect the Gudenåvalley against the motorway].

Etha wind (2016). Finnish wind power projects http://ethawind.com/map/ [accessed September 2016].

Helsingin Sanomat (2015). [Sipilä's Government angered the wind power producers - wind power companies won the first set] erän http://www.hs.fi/kotimaa/a1441939974520 [in Finnish].

Janhunen, S. Hujala, M. and Pätäri, S. (2014). Owners of second homes, locals and their attitudes towards future rural wind farm. Energy Policy 73: 450-460.

https://doi.org/10.1016/j.enpol.2014.05.050

Jensen, C. U., Panduro, T. E., \& Lundhede, T. H. (2014). The Vindication of Don Quixote: The Impact of Noise and Visual Pollution from Wind Turbines. Land Economics, 90(4), 668-682. https://doi.org/10.3368/le.90.4.668 
Jobert, A. and Laborgne, P. and Mimler, S. (2007). Local acceptance of wind energy: Factors of success identified in French and German case studies. Energy Policy 35:5, 2751-276o. https://doi.org/10.1016/j.enpol.2006.12.005

Kautto, M. and Söderholm, D. (2015). [Siipyyn tuulivoimapuiston osayleiskaava] (a draft for municipal plan of Kristinestad for Siipyy)(in Finnish). Ramboll Finland Oy for Kristinestad municipality.

Kelemen, E. et al. (2015) Preliminary guidelines for integrated assessment and valuation of ecosystem services in specific policy contexts. Technical Report. Openness project.

Kosenius, A.K. and Ollikainen, M. 2013. Valuation of environmental and societal trade-offs of renewable energy sources. Energy Policy. 62, 1148-1156.

https://doi.org/10.1016/j.enpol.2013.07.020

Kriström, B. and M.B. Bergman (2014). Samhällsekonomiska analyser av miljöprosjekt - en vägledning. Naturvårdsverket rapport 6628.

Københavns Kommune. (2011a). Vindmøller på Kalvebod Syd. Forslag til tillæg nr. 1 til lokalplan nr. 238 \&quot;Grøften\&quot; Retrieved from https://www.kk.dk/sites/default/files/edoc/e3d69739-fd5f-4dcd-bfo2-eee97b5b8cee/a8757cagae47-4aec-9567-1d34421170b6/Attachments/11776939-12312286-1.PDF

Københavns Kommune. (2011b). Vindmøller på Kalvebod Syd. VVM-redegørelse og miljøvurdering november 2011. København: Københavns Kommune.

Københavns Kommune. (2013). Store vindmøller ved Kalvebod Syd forslag til Kommuneplantillæg med VVM-redegørelse og miljøvurdering. Retrieved from

https://www.kk.dk/sites/default/files/edoc/4ode95f9-bc8c-4c2a-b2do-eff5a4oe1eog/2oc291fcbfcf-4b62-bb8d-4b257d3340e3/Attachments/186a48e7-d50c-4f42-acdd-8f211c1302b4.PDF

Ladenburg, J. (2009). Visual impact assessment of offshore wind farms and prior experience. Applied Energy, 86(3), 380-387. http://doi.org/10.1016/j.apenergy.2008.05.005

Ladenburg, J., \& Dubgaard, A. (2007). Willingness to pay for reduced visual disamenities from offshore wind farms in Denmark. Energy Policy, 35(8), 4059-4071.

http://doi.org/10.1016/j.enpol.2007.01.023

Ladenburg, J., \& Dubgaard, A. (2009). Preferences of coastal zone user groups regarding the siting of offshore wind farms. Ocean \& Coastal Management, 52(5), 233-242.

http://doi.org/10.1016/j.ocecoaman.2009.02.002

Lienhoop, N. and MacMillan, D. (2007). Vauing wilderness in Iceland: estimation of WTA and WTP using the market stall approach to contin-gent valuation. Land Use Policy 24(1), 289-295. https://doi.org/10.1016/j.landusepol.2005.07.001

Lindhjem, H. and S. Navrud (2008). How Reliable are Meta-Analyses for International Benefit Transfers? Ecological Economics 66(2-3): 425-435. https://doi.org/10.1016/j.ecolecon.2007.10.005

Magnussen, K. and S. Navrud (2016) Pilotprosjekt om prissetting av naturinngrep i KVU Grenlandsbanen [Pilot project on the monetary valuation of impacts on nature in the strategic EIA of Grenlandsbanen].

Mason, K. and Milbourne, P. (2014). Constructing a "landscape justice" for windfarm development: The case of Nant Y Moch, Wales. Geoforum. 53, 104-115. https://doi.org/10.1016/j.geoforum.2014.02.012

Mels, Tom; Mels, Sa. (2014). Deltagande landskapsanalys för vindkraft. Retrieved from https://www.naturvardsverket.se/Documents/publikationer6400/978-91-620-66253.pdf?pid $=13812$

Meyerhoff, J., Ohl, C., \& Hartje, V. (2010). Landscape externalities from onshore wind power. Energy Policy, 38(1), 82-92. http://doi.org/10.1016/j.enpol.2009.08.055

Millennium Ecosystem Assessment (MEA) (2005). Ecosystems and Human Well-being: A Framework for Assessment. Island Press, Washington.

Ministry of Environment. (1995). [Government decree on landscapes and development of landscape management.] (in Finnish). 
Morris, D. Calling something a flagship policy doesn't make it one. 2016.

https://sandbag.org.uk/blog/2016/feb/19/how-fix-ets/

Nature protection act. Luonnonsuojelulaki (1096/1996).

Navrud, S. (2007). Practical tools for value transfer in Denmark-guidelines and an example.

Working Report No. 28, 2007, Miljøstyrelsen (Danish Environmental Protection Agency

http://www2.mst.dk/common/Udgivramme/Frame.asp?pg=http://www2.mst.dk/Udgiv/public ations/2007/978-87-7052-656-2/html/kapo6_eng.htm

Navrud, S and R. Ready (eds.) (2007). Environmental Value Transfer: Issues and Methods. Springer Publishers, Dordrect. The Netherlands.

Norwegian Government Agency for Rail Services (NGARS) (2016).

Norwegian Government Agency for Financial Management (NGAFM) (2014).

Nordic Council of Ministers (NCM) (2015). Landscape experiences as a cultural ecosystem service in a Nordic context: Concepts, values and decision-making. Written by H. Lindhjem, R. Reinvang and M. Zandersen. TemaNord 2015:549.

Pohjalainen (2015). [Kristinastad town rejects the Siipyy wind power plan] 21.09.2015 (in Finnish)

Odeck, J. et al. (2015). Brukes samfunnsøkonomiske analyser i prioritering av vegprosjekter? En sammenlikning av Norge og Sverige. [Are cost-benefit analyses used in prioritizing road projects? A comparison of Norway and Sweden]. Samfunnsøkonomen nr. 32015.

Olsen, S.B., Ladenburg, J., Petersen, M.L. Lopdrup, U., Hansen, A.S., Dub-gaard, A. (2005). Motorways versus Nature. A Welfare Economic Valuation of Impacts. ISBN: 87-7992-035-7.

Ostrobothnia Regional Council (2008). [Pohjanmaan maakuntakaava 2030]. (The regional plan until 2030, approved by the Ministry of Environment in 21.12.2010) (in Finnish).

Ramboll Finland Oy (2009). ElA of Siipyy. http://www.ymparisto.fi/fi-

Fl/Asiointi_luvat_ja_ymparistovaikutusten_arviointi/Ymparistovaikutusten_arviointi/YVAhank keet/Siipyyn_edustan_tuulivoimapuisto_Kristiinankaupunki

Santos (2007). Transferring landscape values: How and how accurately? In Navrud, S. And R. Ready (eds): Environmental Valve Transfer, Springer.

Söderholm, P. (2014). En kartläggning och kategorisering av samhällsekonomiska analyser inom miljömålsområdet [A review and categorization of economic analyses in the environmental area]. Rapport for Naturvårdsverket.

Swanwick, C. (2009). Society's attitudes to and preferences for land and landscape. Land Use Policy 26S, pp. S62-S75. https://doi.org/10.1016/j.landusepol.2009.08.025

The Finnish Wind Power Association (FWPA) http://www.tuulivoimayhdistys.fi/en [Accessed September 2016].

Vista Analyse (2016a). Økosystemtjenester i Kystverkets samfunnsøkonomiske analyser. [Ecosystem services in the Coastal Administration's cost-benefit analyses]. Authored by K. Magnussen and S. Navrud. Vista report 2016/21.

Vista Analyse (2016b). Verdsetting av miljørelatert velferdstap ved oljeutslipp fra skip: Kalkulasjonspriser for samfunnsøkonomiske analyser [Valuation of the welfare loss from environmental impacts from oil spills from ships: Values for CBA]. Authored by Henrik Lindhjem, Kristin Magnussen, Ståle Navrud, Sofie Skjeflo, Odd Willy Brude.

Watkiss, P., Downing, T., Handley, C., and Butterfield, R. (2005). The Impacts and Costs of Climate Change. AEA Technology Environment, Stockholm Environment Institute. Commissioned by European Commission DG Environment.

Zaunbrecher, B. and Ziefle, M. (2016). Integrating acceptance-relevant factors into wind power planning: A discussion. Sustainable Cities and Society. 27, 307-314.

https://doi.org/10.1016/j.scs.2016.08.018 



\section{Sammendrag}

\section{Baggrund og motivation}

Fase 1 i dette projekt viste at Vurderinger af Virkninger på Miljøet (VVM), Costbenefit analyser (CBA) og rumlig planlægning ofte udføres uden at kvantificere indflydelsen på landskaber eller uden at vurdere værdien af landskabspåvirkninger på velfærd (NCM 2015). Adskillige indikatorer og metoder er blevet udviklet til at kvantificere og værdisætte ændringer i landskaber og resulterende tab af økosystemtjenester i monetære eller ikkemonetære termer, baseret på folks præferencer fra spørgeskemaundersøgelser eller observeret gennem markedsadfærd. NCM (2015) evaluerede sådanne studer samt forskellige statistikker fra Norden og fandt at uønskede landskabsændringer, især fra større infrastruktur projekter, kan forårsage potentielt store velfærdstab relaterede til en degraderet landskabsoplevelse. Disse tab er i dag i høj grad ikke inkluderede i alle Nordiske landes planlægningsprocesser (NCM 2015).

Efter at have evalueret og diskuteret koncepter for, hvad litteraturen siger omkring landskabsværdier og udvalgte beslutningskontekster i de nordiske lande (NCM 2015), går vi i denne rapport videre til at demonstrere, hvordan værdier af landskabsoplevelser bedre kan integreres i praksis.

\section{Mål og afgrænsninger}

Formålet med anden fase af dette projekt er at undersøge og demonstrere, hvordan $ø$ øosystemtjenestetilgangen og værdier af landskabsoplevelser bedre kan integreres i praksis igennem egentlige eksempler med potentielt store påvirkninger af landskabet.

\section{Diskussion og anbefalinger}

\section{Vurdering af landskabserfaringer: en menneske baseret tilgang}

Vores udgangspunkt er landskabsdefinitionen fra den Europæiske Landskabs Konvention: "Landskab: et område - som opfattet af mennesker - hvis egenart er resultatet af naturlige og/eller menneskelige faktorers påvirkning og gensidige påvirkning." Artikel 5 i konventionen understreger en forpligtelse til at sikre offentlighedens (udover lokale og regional myndigheders samt andre interessenters) inddragelse i udformningen og gennemførelsen af landskabspolitikker og at der etableres procedurer for at dette sker. Dermed slår konventionen fast at folks 
præferencer for landskabsoplevelser bør tælle (mere) i policy processer som har en betydelig indflydelse på landskaber.

\section{Kulturelle økosystemtjenester relaterede til landskabsoplevelser}

For at kunne gøre landskabsoplevelsen operationel i forhold til miljøvurderinger og planlægning har vi forenklet kategorierne omkring kulturelle økosystemtjenester i relation til landskabsoplevelser (Se Tabel A). Vi foretog forenklingen ved at sammenlægge flere detaljerede kategorier til to brede kategorier: "Naturarv" og "Kultur arv og identitet". Derudover har vi kategorierne "rekreative" og "æstetiske" services.

Tabel 19: En forenklet oversigt over kulturelle økosystemtjenester relateret til landskabsoplevelser

$\begin{array}{ll}\text { \# } & \text { Kulturelle økosystemtjenester } \\ 1 & \begin{array}{l}\text { Rekreation: muligheder for turisme og rekreative aktiviteter, bl.a. aktiviteter som gåture, sport/træning og } \\ \text { andre turistrelaterede aktiviteter }\end{array} \\ & \begin{array}{l}\text { Astetisk: påskønnelse af naturlandskab (andet end deciderede rekreative aktiviteter) som at køre på } \\ \text { maleriske ruter eller nydelsen af udsigter fra et hotel eller hjemmefra }\end{array} \\ & \begin{array}{l}\text { Naturarv: ekskursioner og feltture med uddannelsesmæssige eller kreative formål; især landskaber som har } \\ \text { spirituel og religiøs betydning, og landskaber eller landskabstræk som har inspirationsværdi }\end{array} \\ & \begin{array}{l}\text { Kulturarv og identitet: stedsidentitet og tilhørsforhold. Dette omfatter aktiviteters som at reflektere eller } \\ \text { meditere over kulturarv indlejret i et bestemt landsskab, eller unikheden ved et bestemt landskab. Dette kan } \\ \text { finde sted både når man er i landskabet er eller når mand tænker på eller læser om landskabet. }\end{array}\end{array}$

\section{En trinvis metode til at vurdere, værdisætte og integrere landskabseffekter}

Vi har udviklet en enkel trinvis metode, som bruger økosystemtjenestekategorierne fra Tabel 19 til at vurdere, værdisætte og integrere påvirkninger på landskabsoplevelser i praksis. Metoden kan anvendes i VVMer og i CBAer til at integrere og kvantificere folks præferencer og meninger. Hvor store landskabspåvirkninger fra transportprojekter og energiinfrastrukturprojekter kan være for landskabsoplevelsen afhænger i høj grad af lokaliteten, skala og de visuelle effekter. Påvirkninger af "hverdagslandskabet" i og omkring større byområder kan have større velfærdskonsekvenser end påvirkningerne i mere fjerntliggende ikoniske landskaber, hvor der ikke bor så mange mennesker.

Som landskaber ændres, kan økosystemtjenester som folk drager nytte af ændres mere eller mindre. Eftersom ikke alle landskabspåvirkninger har en større betydning for økosystemtjenester foreslår vi en trinvis metode der starter med en screening for at fastlægge de mest berørte økosystemtjenester. Derefter følger en mere detaljeret vurdering og monetær værdisætning, hvor dette er muligt, af de mest berørte økosystemtjenester. Påvirkningerne, som ikke kan værdisættes monetært vurderes kvalitativt, men stadig med henblik på at vise, hvor vigtige effekterne er for folks velbefindende. 


\section{Overblik over case studies omkring offentlige infrastrukturprojekter}

Vi har valgt 3 dybdegående case studier som dækker et jernbaneprojekt i Norge og to vindprojekter i henholdsvis Danmark og Finland. Derudover inkluderer vi en række andre cases fra Danmark og Norge (begge vejprojekter) og Island (energiprojekter) for at illustrere brugbarheden og udfordringerne ved at integrere påvirkninger på landskabsoplevelser.

Jernbanecasen fra Norge er et ret unikt eksempel, hvor vi har haft mulighed for at arbejde med en aktuel case mens planlægnings og analysearbejdet pågik. Specifikt blev en strategisk miljøvurdering (dvs. på et mere generelt niveau før VVM på projekt niveau) udført med input i form af databehov for at kunne gennemføre en mere grundig vurdering af velfærdseffekter ved projektet. VVM'en indeholdt ikke kvantificerede informationer om den berørte del af befolkningen eller størrelsen af påvirkningerne. Men ved at udføre flere analyser, gøre nogle plausible antagelser og overføre værdier fra litteraturen har vi været i stand til at illustrere de potentielle velfærdseffekter for de væsentligste økosystemtjenester der forventes påvirkede af landskabsændringerne. Selv om den endelige linjeføring ikke er fastlagt endnu, kan vi fastslå at case studiet har skabt en opmærksomhed overfor vigtigheden af også at værdisætte velfærdstab af økosystemtjenester i monetære termer.

Vindkraftcasen fra Danmark er en VVM omkring fire store landvindmøller i udkanten af Københavns Kommune. Casen var anfægtet af nabokommunen og beboere pga. forventede visuelle negative påvirkninger. Selvom projektet fik dispensation fra Miljøbeskyttelsesloven af Miljøministeriet, blev VVM'en afvist af Natur og Miljøklagenævnet. Ved at anvende økosystemtjenesterammen samt den trinvise metode og værdisætning af degraderede æstetiske økosystemtjenester fandt vi indikationer på væsentlige negative værdier, som kunne have spillet en central rolle i VVM konklusionerne sammenlignet med den rent kvalitative beskrivelse, som udelukkede en af de primære effekter.

Den udvalgte finske case er en VVM af en foreslået offshore vindmøllepark i nærheden af kystbyen Siipyy. Vindmølleparken var planlagt $i$ et område udlagt til vindmøller i regionplanen, men pga. lokal modvilje i byrådet blev projektet forkastet $\mathrm{i}$ lokalplanen og projektet stoppet. Monetær værdisætning af påvirkningen af vindmølleparken i forhold til kulturelle landskabsøkosystemtjenester kunne have givet beslutningstagerne nye og væsentlige informationer ikke blot omkring størrelsen af påvirkningen men også omkring præferencerne blandt de forskellige befolkningsgrupper der kunne blive påvirket.

Selvom ingen af de strategiske eller projekt VVM'er anvendte økosystemtjenesterammen omfatter de informationer omkring tilstand og effekter som kan relateres til forskellige landskabsøkosystemtjenester. En række indsigter og anbefalinger kan udledes af de dybdegående case studier:

- Mange af de tilgængelige informationer i VVM'erne kan benyttes til en vis grad at beskrive tilstanden (dvs. hvor meget af økosystemtjenesterne er til stede før den 
foreslåede forandring) og forandringsindikatorer (dvs. hvilke funktioner i landskabet forandres efter det foreslåede projekt er implementeret).

- Ved at anvende en økosystemtjeneste tilgang ved evaluering af påvirkninger og betydning for de enkelte landskabsrelaterede økosystemtjenester kan man sikre sig at alle relevante befolkningsgrupper bliver identificeret og ingen udelukkes.

- For at kunne kvantificere påvirkning af VVM-krævende projekter på landskabsoplevelser indebærer det at vurdere størrelsen af befolkningen som påvirkes og de rumlige aspekter af påvirkningen, før det er muligt at foretage en monetær værdisætning.

- Ved at inkludere ekstra geografiske information system (GIS) analyser, husholdnings- og brugerundersøgelser af forskellige befolkningsgrupper i VVM processen vil det være muligt at fortage overførsler af værdier fra andre studier omkring værdien af ændringer i landskabsrelaterede økosystemtjenester.

- I den udstrækning at spørgeskemaundersøgelser allerede i dag anvendes i VVM processen, kunne de udvides til at imødekomme en økosystemtjenestetilgang som er baseret på befolkningens præferencer.

- Case studierne viste at to-trinsmetoden, der starter med en screening, scoring og derefter en mere dyberegående analyse af udvalgte økosystemtjenester, både er relevant og brugbar. Case studierne viste også at det er nødvendig at generere ekstra informationer i VVM processen. Denne slags informationer indebærer ikke nødvendigvis høje omkostninger, eftersom de kan indhentes gennem den eksisterende proces og samtidig skabe en højere kvalitet i VVM'erne.

Vores enkle trinvise metode er et første forsøg på at gå fra et koncept omkring landskabsoplevelser til at udføre en vurdering i praksis. Metoden har givet en første måde at tænke på, hvordan landskabsoplevelser bedre kan vurderes i projekter med offentlige infrastrukturanlæg, som har potentielt store negative landskabspåvirkninger. Case studierne har vist, at selv ved mangel på informationer til at udføre værdisætning, hjælper den trinvise metode til bedre at inkludere potentielle påvirkninger på befolkningen i VVM dokumentationen. Det betyder at basis for beslutninger kan blive mere robust og kan fokusere på de mest væsentlige aspekter, dvs. hvordan befolkning ser landskabseffekterne gennem deres egne øjne, så at sige.

Der er stadig nogle problemstillinger som er nødvendige at løse i forhold til at videreudvikle og teste den trinvise metode; i forhold til at opbygge en tilstrækkelig stor pulje af primære værdisætningsstudier omkring landskabspåvirkninger; i forhold til at skelne mellem landskabsøkosystemtjenester som er relativt ligetil at værdisætte monetært (fx rekreation, æstetiske services) og de tjenester hvor vurderingerne snarere bør forblive kvalitative ( $\mathrm{fx}$ kultur- og naturarv og stedsidentitet); og i forhold til at integrere metoden i VVM og CBA guidelines. 
Nordic Council of Ministers

Ved Stranden 18

DK-1061 Copenhagen K

www.norden.org

\section{Assessing landscape experiences as a cultural ecosystem service in public infrastructure projects}

Undesirable landscape changes, especially from large infrastructure projects, may give rise to large welfare losses due to degraded landscape experiences. These losses are largely unaccounted for in Nordic countries' planning processes. There is a need to develop practical methods of including people's preferences and the value of landscape impacts in policy assessments and decision-making. The project aims to explore how the ecosystem service approach and values of landscape experiences can be better incorporated in actual cases. The project developed a two-step approach to assess, value and incorporate landscape impacts and tested these in case studies based on EIA documentation. We found that despite the lack of information generated in the EIAs, the step-wise method significantly improved upon evidence and conclusions of how people are impacted due to landscape changes. 